\title{
New Perspectives on Iron-Based Nanostructures
}

\author{
Seyedeh-Masoumeh Taghizadeh ${ }^{1,2}$, Aydin Berenjian ${ }^{3, *}$, Marziyeh Zare ${ }^{4}$ \\ and Alireza Ebrahiminezhad ${ }^{5, *}$ \\ 1 Biotechnology Research Center, Shiraz University of Medical Sciences, Shiraz 71468-64685, Iran; \\ taghizm@sums.ac.ir \\ 2 Department of Pharmaceutical Biotechnology, School of Pharmacy and Pharmaceutical Sciences Research \\ Center, Shiraz University of Medical Sciences, Shiraz 71468-64685, Iran \\ 3 School of Engineering, Faculty of Science and Engineering, The University of Waikato, \\ Hamilton 3240, New Zealand \\ 4 Department of Molecular Medicine, School of Advanced Medical Sciences and Technologies, \\ Shiraz University of Medical Sciences, Shiraz 71336-54361, Iran; taghizm@yahoo.com \\ 5 Department of Medical Nanotechnology, School of Advanced Medical Sciences and Technologies, \\ Shiraz University of Medical Sciences, Shiraz 71336-54361, Iran \\ * Correspondence: aydin.berenjian@waikato.ac.nz (A.B.); a_ebrahimi@sums.ac.ir (A.E.)
}

Received: 5 August 2020; Accepted: 24 August 2020; Published: 10 September 2020

\begin{abstract}
Among all minerals, iron is one of the elements identified early by human beings to take advantage of and be used. The role of iron in human life is so great that it made an era in the ages of humanity. Pure iron has a shiny grayish-silver color, but after combining with oxygen and water it can make a colorful set of materials with divergent properties. This diversity sometimes appears ambiguous but provides variety of applications. In fact, iron can come in different forms: zero-valent iron (pure iron), iron oxides, iron hydroxides, and iron oxide hydroxides. By taking these divergent materials into the nano realm, new properties are exhibited, providing us with even more applications. This review deals with iron as a magic element in the nano realm and provides comprehensive data about its structure, properties, synthesis techniques, and applications of various forms of iron-based nanostructures in the science, medicine, and technology sectors.
\end{abstract}

Keywords: Fe nanomaterials; Fe nanoparticles; ferric; ferrous; iron ores; synthesis methods

\section{Introduction}

Iron, in terms of mass, is the most abundant element on Earth. This element is an important constituent of the earth's outer and inner cores, and the fourth most important element in the earth's crust. Among all minerals, iron is one of the early elements identified by the human beings to be taken advantage of and used. It made an era in the ages of humanity; namely, the Iron Age is identified as the final epoch of the three-age division of the prehistoric ages. This came after the Bronze Age, when the human beings reached superior strength and hardness in tools and weapons by iron. In fact, the age of iron did not come to an end, but developed until the 21st century life. The United States of America alone produced $\sim 49$ million metric tons of iron ore in 2018. This number is larger for the world's largest iron ore mine producers, with Australia and Brazil, countries which produce 900 million and 490 million metric tons, respectively [1].

Pure metallic iron is rarely found on the lithosphere because, in the presence of oxygen and moisture, it will cause it to readily oxidize. In order to obtain metallic iron, oxygen must be removed from natural ores by reduction. From a chemical point of view, iron, with the chemical symbol "Fe" (from Latin: ferrum), is an element with an atomic number of 26, and is located in the first round of the transition metals. It is also the head of ferromagnetic materials. The D orbital of iron ([Ar] $3 \mathrm{~d}^{6} 4 \mathrm{~s}^{2}$ ) 
is not totally full (Figure 1) and can have different oxidation states. The most important states of iron oxidation are ferrous $\left(\mathrm{Fe}^{2+}\right)$ and ferric $\left(\mathrm{Fe}^{3+}\right)$. Ferrous iron links to sulfur and nitrogen ligands as well as oxygen ligands. Ferric iron tends to react to hard ligands, such as oxygenated ligands. The most common coordination number for iron (II) and iron (III) is six, which has an octagon spatial arrangement. Furthermore, for ferrous/ferric iron, there is also a tetrahedral arrangement (a coordination number of four), and also a square pyramid or a trigonal bipyramid (especially in a complex coordination of five).

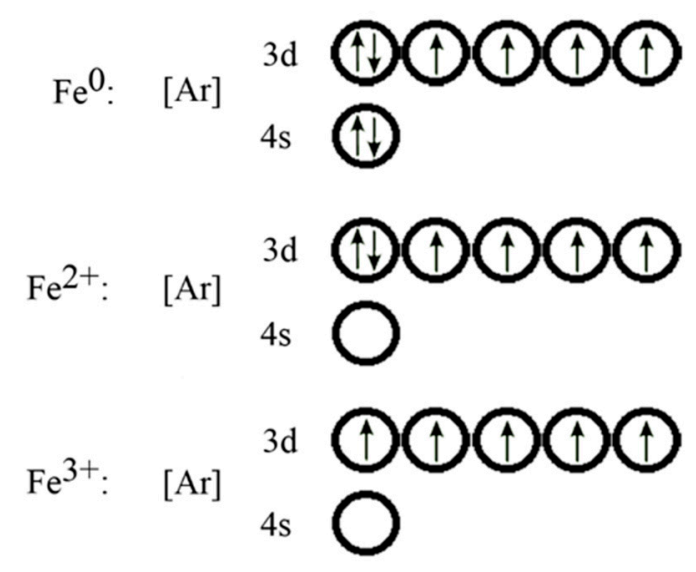

Figure 1. Orbital diagram for iron and iron ions.

Iron has a shiny grayish-silver color but after combination with oxygen and water can make various forms of iron oxide, iron oxide hydroxide, and iron hydroxide. This diversity sometimes appears ambiguous but provides a colorful array of materials with divergent properties and applications. By taking this color pen set to the nano realm, it provides us with even more colors. The current review is dealing with this magic element and provides a wide view of iron, iron oxide, iron oxide hydroxide, and iron hydroxide in the nano realm.

\section{Zero-Valent Iron}

The appearance of pure iron ranges from silver to black or gray and has a metallic sheen with ferromagnetic properties. Pure iron is not used in the industry because of its softness and lack of sturdiness. Iron is usually used along with nonmetal elements (carbon, sulfur, phosphorus, and silicon), and sometimes with other metals (chromium, nickel, vanadium, and molybdenum) in alloy form, where the resultant product would be steel or cast iron. The cheap price and high strength of iron alloys have commoditized their use in the automotive industry, the hull of large ships, and buildings. Nanoparticles of pure iron are known as zero-valent iron nanoparticles (ZVINPs) and are usually synthesized by chemical reduction of iron ions [2]. In this manner, reducing agents, such as sodium borohydride ore hydrazine, are used to reduce iron ions to iron atoms and subsequently iron atoms aggregate and form ZVINPs [3,4]. In addition to chemical reducing agents, some biochemical species are also able to reduce iron ions, and hence can be employed for the bio-reduction of iron ions to ZVINPs [5,6]. In comparison to chemical reduction reactions, in the bio-reduction reactions, no additional molecule is required to stabilize nanoparticles. Biologic molecules are sufficient for both the reduction and protection of the prepared particles [5,7-9]. However, when chemical reducing agents are employed, a second protective molecule is required to stabilize the particles (Figure 2).

Generally, ZVINPs are unstable and tend to oxidize and hydrate iron into oxides and iron hydroxides (4). In fact, ZVINPs usually exhibit the dual characteristics of iron $\left(\mathrm{Fe}^{0}\right)$ and iron oxides or hydroxides. This feature is due to oxidation of exposed iron atoms on the surface of particles and the formation of an iron oxide/hydroxide shell around the zero-valent core (see Section 4.1.3) [2,7-9]. In order to prevent the oxidation reactions and maintain the properties of ZVINPs, coating with noble metals can be used. For instance, ZVINPs with gold or silver coating are effective in the treatment of cancer, and can 
suppress the growth of cancer cells while possessing adequate biocompatibility with nonmalignant cells $[10,11]$. Minerals are the other applicable material to protect zero-valent iron nanoparticles. For instance, montmorillonite, which is a clay mineral, has been used as an effective protective agent and support [2]. In some investigations chelating agents, such as diethylenetriaminepentaacetic acid (DTPA), were used as a stabilizer for ZVINPs [7]. Biologic compounds were also shown to be effective for protection from oxidation. These compounds can make a thick coating around the particles and protect them from oxidation. It has been shown that by using biologic coatings any detectable iron oxides can be formed on the particles [5,12].

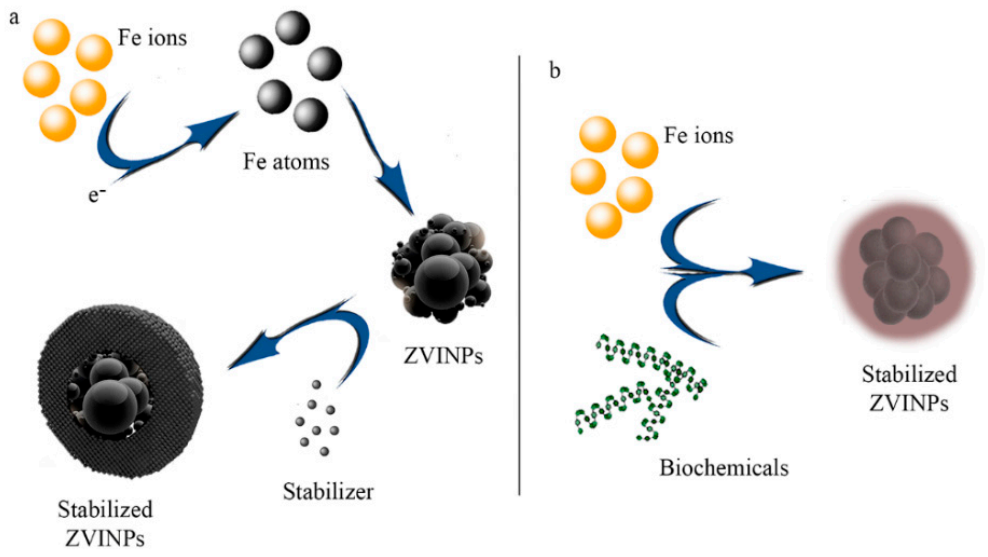

Figure 2. Chemical (a) and biological (b) reduction of iron ions to zero-valent iron nanoparticles (ZVINPs) and their stabilization.

ZVINPs gained diverse applications in environmental sciences and remediation proposes. These nanoparticles are used to remove arsenic from contaminated aquatic environments $[13,14]$. Extensive lab studies have shown the potency of these nanoparticles in the adsorption and degradation of halogenated hydrocarbons, such as trichloroethylene (TCE) [15]. These nanoparticles are also effective against pesticides, transition metals, organic dyes, and radioactive contaminations [7,16-18]. ZVINPs can also act as an antimicrobial agent which have a better performance in the absence of oxygen. The antimicrobial activity of these nanoparticles against Escherichia coli has been studied under anaerobic and aerobic conditions. In the absence of oxygen, when $E$. coli is exposed to $9 \mathrm{mg} / \mathrm{L}$ of iron nanoparticles for $10 \mathrm{~min}$, bacterial cells were effectively disabled. In aerobic conditions, when the bacteria were exposed to $90 \mathrm{mg} / \mathrm{L}$ of iron nanoparticles for $90 \mathrm{~min}$, the antimicrobial effects were negligible, since, in the presence of oxygen, ZVINPs are oxidized [19].

\section{Iron Oxides}

In the presence of oxygen and humidity, iron easily combines with oxygen and transforms to iron oxides. Iron oxides are widespread in nature and can be found in soil, rocks, lakes, rivers, seafloors, and even in living creatures [20]. Generally iron oxides receive much attention from scientists and researchers because of the variety in their physical and chemical properties. Iron reacts with oxygen in various states and therefore can be found in diverse chemical formulas with different properties as described in the following.

\subsection{Ferrous Oxide (FeO)}

Fritz Wüst, a German metallurgist (1860-1938), named iron (II) oxide (ferrous oxide, Fe=O, Figure S1) as wüstite. It is a gray-black ore with a greenish shade. The FeO formula is not exactly correct because wüstite is a typical non-stoichiometric mineral. In this mineral the amount of iron is always less than the stoichiometric ratio, and there is no temperature at which a one-to-one ratio can be seen between iron and oxygen. In fact, there is deficient iron in the structure with compositions 
ranging from $\mathrm{Fe}_{0.84} \mathrm{O}$ to $\mathrm{Fe}_{0.95} \mathrm{O}\left(\mathrm{Fe}_{1-\mathrm{x}} \mathrm{O}\right)$ [21]. It has an isometric (cubic) crystal system and has anti-ferromagnetic properties [22].

The most common methods for preparing wüstite nanoparticles are co-precipitation (Scheme 1), polyol method (Scheme 2), pyrolysis (thermal decomposition) of organometallic compounds (Scheme 3), micro emulsion, hydrothermal (Scheme 4), and sol-gel synthesis (Scheme 5) [23]. Among these methods, thermal decomposition of iron (II) or iron (III) complexes is the most employed technique [22,24,25]. wüstite nanoparticles can also be fabricated by physical approaches, such as ball milling, using a mixture powder of hematite and iron [26]. The main challenge in all the above-mentioned methods for preparing wüstite nanoparticles is to achieve nanoparticles with controlled size, shape, and composition [23].

Wüstite nanoparticles are semi-stable, and are therefore used in the creation of mixed phase nanoparticles [27]. Moreover, in order to create stability in wüstite nanoparticles, they are covered with organic ligands. In another approach, wüstite nanoparticles can be doped with other divalent metals $(\mathrm{Dm})$, such as cobalt and magnesium, to fabricate $\operatorname{Dm}_{(\mathrm{x})} \mathrm{Fe}_{(1-\mathrm{x})} \mathrm{O}$. These structures can be synthesized by the thermal decomposition of DmFe organometallic complexes or by solution-combustion methods $[28,29]$. The surface of the doped wüstite nanoparticles is oxidized to $\mathrm{DmFe}_{2} \mathrm{O}_{4}$ and form a shell to protect the core from oxygen transmission. The thickness of the oxidized shell can be tuned through a controllable oxidation process and has significant effects on the core/shell ratio and exchange bias properties. For instance, it has been shown that a shell of $\mathrm{CoFe}_{2} \mathrm{O}_{4}$ with $4 \mathrm{~nm}$ thickness is ideal for resistance to oxygen transmission [29].

From application point of view, there are reports for the antimicrobial properties of wüstite nanostructures. It has been shown that the nanochains of carbon coated wüstite nanoparticles can kill bacterial cells within a short incubation time at minimal dosages [30]. Wüstite nanoparticles can be applied as radiation filters. Glasses with thin films of $\mathrm{FeO}$ and $\mathrm{Fe}_{2} \mathrm{O}_{3}$ nanoparticles are used as solar radiation filters. These filters are applicable on the building windows to prevent heat transmittance while visible light is passing through [31].

\section{Precursor INPs}

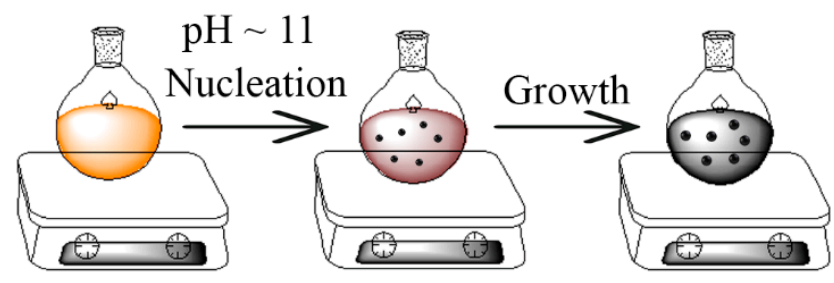

Scheme 1. Schematic illustration of a common precipitation reaction, INPs stands for iron nanoparticles.

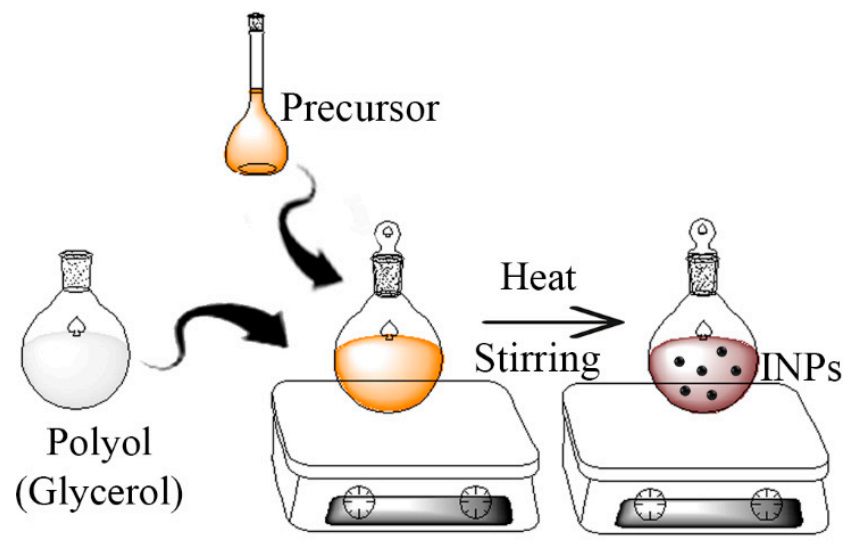

Scheme 2. Schematic illustration of a polyol reaction. 


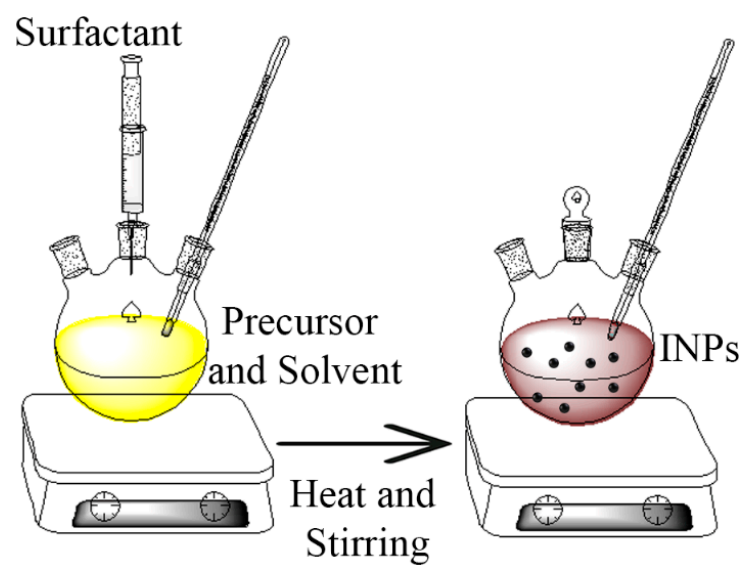

Scheme 3. Schematic illustration of a pyrolysis reaction.

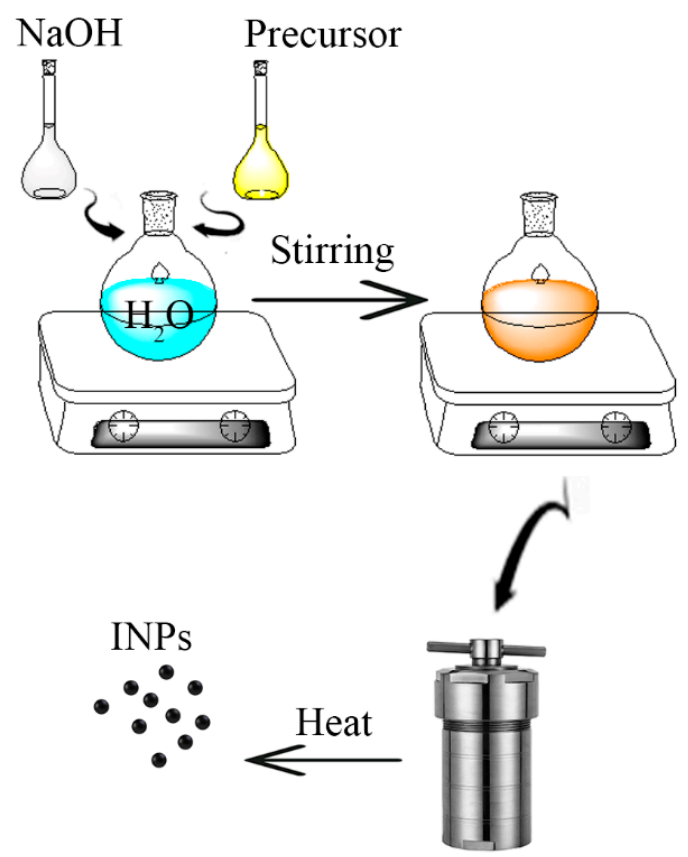

Scheme 4. Schematic illustration of hydrothermal synthesis reaction.

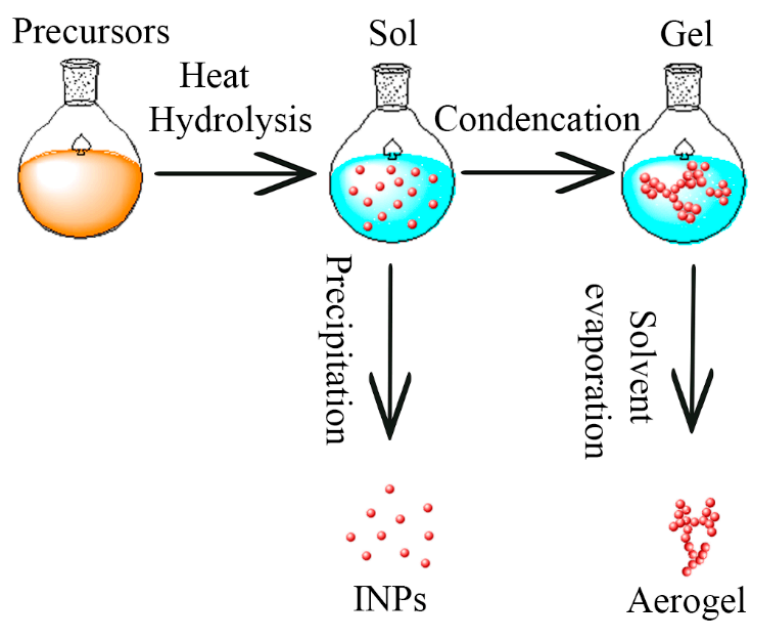

Scheme 5. Schematic illustration of a sol-gel reaction. 


\subsection{Ferric Oxide $\left(\mathrm{Fe}_{2} \mathrm{O}_{3}\right)$}

As its name indicates, ferric oxide is the oxide of iron (III) $(\mathrm{O}=\mathrm{Fe}-\mathrm{O}-\mathrm{Fe}=\mathrm{O}$, Figure $\mathrm{S} 1)$. This form of iron oxide is well-known as rust and can be found in red and brown. Ferric oxide is the result of dehydration reaction of $\mathrm{FeO}(\mathrm{OH})$ and $\mathrm{Fe}(\mathrm{OH})_{3}$ at temperatures above $200{ }^{\circ} \mathrm{C}$ (Equations (1) and (2)). It can be found in its hydrated (see Section 3.2.2) or anhydrous forms. In the following we made a detailed reviews on the various phases of anhydrous ferric oxides.

$$
\begin{aligned}
& 2 \mathrm{FeO}(\mathrm{OH}) \rightarrow \mathrm{Fe}_{2} \mathrm{O}_{3}+\mathrm{H}_{2} \mathrm{O} \\
& 2 \mathrm{Fe}(\mathrm{OH})_{3} \rightarrow \mathrm{Fe}_{2} \mathrm{O}_{3}+3 \mathrm{H}_{2} \mathrm{O}
\end{aligned}
$$

\subsubsection{Anhydrous Ferric Oxides}

Anhydrous forms of ferric oxide can be found in different polymorphs, such as alpha $\left(\alpha-\mathrm{Fe}_{2} \mathrm{O}_{3}\right)$, beta $\left(\beta-\mathrm{Fe}_{2} \mathrm{O}_{3}\right)$, gamma $\left(\gamma-\mathrm{Fe}_{2} \mathrm{O}_{3}\right)$, and epsilon $\left(\varepsilon-\mathrm{Fe}_{2} \mathrm{O}_{3}\right)$. These minerals are the same in chemical structure but have differences in their crystal systems [32].

Hematite $\left(\alpha-\mathrm{Fe}_{2} \mathrm{O}_{3}\right)$

The word hematite is taken from the Greek word hematicos, which means bloody. The chemical reaction to get hematite from magnetite is shown in Equation (3). Hematite is a widespread iron oxide and can be found in rocks and soil. It is the oldest known ore of iron that has ever formed on the Earth.

$$
2 \mathrm{Fe}_{3} \mathrm{O}_{4}+1 / 2 \mathrm{O}_{2} \rightarrow 3\left(\alpha-\mathrm{Fe}_{2} \mathrm{O}_{3}\right)
$$

Hematite has a rhombohedral and hexagonal crystal system, and its crystal habit can be seen as either spindle, bar, oval, square, or spherical. It has a red metallic appearance. Hematite has different forms, but all forms have a red sheen. Hematite iron deposits are most significant in the steel industry and in the preparation of cast iron. This mineral is one of the precious rocks, and the fine cuts of its black crystals are used in making jewelry. Moreover, its powder is used in pigments, such as red pigment 22 and antirust [20].

The most common ways to produce hematite nanoparticles are chemical precipitation, the polyol process, pyrolysis of organometallic compounds, micro emulsion, hydrothermal synthesis, and sol-gel process $[23,33,34]$. These nanoparticles can also be obtained by calcination of mixtures of iron oxide nanoparticles at high temperatures (about $500{ }^{\circ} \mathrm{C}$ ) [35]. Biosynthesis (plant mediated synthesis) is another route, in fact, a green route, for fabrication of hematite nanoparticles [36]. These particles can be fabricated by using various plants, such as root extract of Arisaema amurense [37], Tragacanth gel [38], Citrus reticulum peels extract [39], the extract of green tea leaves (Camellia sinensis) [40], Ailanthus excelsa [36], and guava (Psidium guajava) [41].

Hematite nanoparticles are the most stable iron nanostructure in the ambient conditions and have size and shape-dependent magnetic properties. The magnetic saturation is in direct relation to particle size, and by increasing the size, an increase in the magnetic saturation value can be observed. On the other hand, it has been shown that spherical nanoparticles have the highest magnetic saturation, while cubic and ellipsoidal nanoparticles are ranked in the next positions, respectively [42]. These nanoparticles can exhibit ferromagnetism or superparamagnetic behavior at room temperatures. However, in contrast to magnetite $\left(\mathrm{Fe}_{3} \mathrm{O}_{4}\right)$ nanoparticles, saturation magnetization values of hematite nanoparticles are very low [43]. These nanostructures have gained applications in the development of electrochemical devices, as cathode in lithium batteries, the fabrication of photo electrochemical systems to produce hydrogen from water using solar radiation, as photo reactive nanomaterial for the enhanced performance of photoelectrochemical cells, and as reusable catalysts $[23,40,44]$. These nanoparticles can be employed for the enhancement of the thermal conductivity of the base fluids in nanofluidic systems [41]. Hematite nanoparticles have a high capacity for metal ions' removal from aqueous 
solutions. These particles can be employed for metal cations removal from acid mine drainage. It has been shown that hematite nanoparticles can completely remove aluminum, magnesium, manganese, and iron ions, while zinc and nickel ions remove over $80 \%$ and sodium and calcium ions remove up to $72 \%$ [35]. Hematite nanostructures are also able to decontaminate aqueous systems from different organic pollutants and can be used as an effective material in fertilizers fabrication [39]. The surface modification of hematite nanoparticles with the organic functional groups makes these particles more biocompatible and suitable to treat the chlorosis in plants, such as Glycine max [45].

Beta- $\mathrm{Fe}_{2} \mathrm{O}_{3}\left(\beta-\mathrm{Fe}_{2} \mathrm{O}_{3}\right)$

$\beta-\mathrm{Fe}_{2} \mathrm{O}_{3}$ is a scarce form of iron (III) oxides. This polymorph is a metastable phase and easily transformed into the more stable alpha $(\alpha-)$ phase of ferric oxide. The transformation occurs at high temperatures, above $500{ }^{\circ} \mathrm{C}$, but the mechanism of transformation and the changes which occur in crystal structure are, as yet, unclear. In fact, the exact crystal structure of the $\beta-\mathrm{Fe}_{2} \mathrm{O}_{3}$ is not defined, and this is due to difficulties in obtaining a $\beta$ phase in pure monophasic crystals [46]. $\quad \beta-\mathrm{Fe}_{2} \mathrm{O}_{3}$ was discovered in 1958 and believed to have a cubic body centered crystal structure [47]. However, techniques for the fabrication of $\beta-\mathrm{Fe}_{2} \mathrm{O}_{3}$ nanostructures have been developed and these structures can be obtained via simple chemical reactions. Solid state reaction is one of the most common techniques for the fabrication of $\beta-\mathrm{Fe}_{2} \mathrm{O}_{3}$ nanoparticles, where $\mathrm{NaFe}\left(\mathrm{SO}_{4}\right)_{2}$ is used as the precursor. In brief, a solution mixture of $\mathrm{Fe}_{2}\left(\mathrm{SO}_{4}\right)_{3}$ and $\mathrm{Na}_{2} \mathrm{SO}_{4}$ is evaporated in an oven at ambient atmosphere to obtain $\mathrm{NaFe}\left(\mathrm{SO}_{4}\right)_{2}$. The resulting powder is then fully grounded and mixed with $\mathrm{NaCl}$, in a 1:2 ratio, and heated up to $400-500{ }^{\circ} \mathrm{C}$ in a muffle furnace. After cooling, the product should be dispersed in distilled water and washed to remove $\mathrm{NaFe}\left(\mathrm{SO}_{4}\right)_{2}$ and $\mathrm{Na}_{3} \mathrm{Fe}\left(\mathrm{SO}_{4}\right)_{3}[46,47]$. In addition, colloidal $\beta-\mathrm{Fe}_{2} \mathrm{O}_{3}$ nanostructures can be fabricated by hydrolysis of ferric ions in boiling water. The shape of prepared nanostructures can be controlled by the employing cobalt ions $\left(\mathrm{Co}^{2+}\right)$. It has been shown that spherical and rod nanoparticles can be obtained in this order [48].

Water splitting and hydrogen production is one of the most promising approaches to overcoming the global energy crisis. Water splitting can be performed via photoelectrochemical reactions which employ ferric oxide nanoparticles as the photoanode material. Due to availability, photochemical stability, and high efficiency for light absorption, in the past decades, hematite $\left(\alpha-\mathrm{Fe}_{2} \mathrm{O}_{3}\right)$ has been envisioned as a strong semiconductor photocatalyst. However, there are some obstacles with hematite. For instance, its low conductivity reduces the photoelectrochemical activity and there are also some other defects, such as large over potential and short hole transport distance. Recent studies introduced $\beta-\mathrm{Fe}_{2} \mathrm{O}_{3}$ as a more promising phase for light assisted water splitting. $\beta-\mathrm{Fe}_{2} \mathrm{O}_{3}$ has a smaller band gap than hematite and therefore is more efficacious in light absorption and photoelectrochemical reactions [47].

Maghemite $\left(\gamma-\mathrm{Fe}_{2} \mathrm{O}_{3}\right)$

Maghemite is the second most abundant form of ferric oxide. It has a cubic and tetragonal crystal system and its crystal habit is cube, plate, or spindle in shape. The color of maghemite is brown or reddish brown. Its combination is metastable and at high temperatures (about $500{ }^{\circ} \mathrm{C}$ ), it turns into the alpha phase. Maghemite has ferrimagnetic properties and its nanoparticles show superparamagnetic properties $[49,50]$. The most common techniques for maghemite nanoparticles production are co-precipitation, polyol process, micro emulsion, hydrothermal synthesis, sol-gel process, and the pyrolysis of organometallic compounds [23]. These particles can also be obtained by the oxidation of magnetite $\left(\mathrm{Fe}_{3} \mathrm{O}_{4}\right)$ nanoparticles via thermic treatments [50-52]. The conversion of magnetite to maghemite can also be seen on the surface of magnetite nanoparticles that forms a core-shell structure of magnetite-maghemite [53]. To improve the properties of the prepared nanostructure, the surface of the maghemite, nanoparticles can be functionalized using divergent biocompatible compounds, such as amino acids, fatty acids, silica, and hydroxyapatite [52]. Surface modifications were also done by multiwall carbon nanotubes (MWCNTs) and ethylenediaminetetraacetic acid (EDTA) [52]. 
Even polymeric materials have been used [54-56]. Doping is another approach to improve the properties and functionalities of maghemite nanoparticles. For instance, these nanoparticles can be doped with rare-earth elements, such as yttrium [57]. On the other hand, maghemite nanoparticles themselves can be used for the decoration of other nanostructures, such as carbon nanotubes. Maghemite nanoparticles decorated on carbon nanotubes have been used for the fabrication of oxygen evolution reaction (OER) electrocatalysts [58]. Also, maghemite nanoparticles are used in magnetic recording media, biocompatible magnetic fluid production, and electro chromic devices [23].

The other well studied application of maghemite nanoparticles is in the environmental sciences. These nanoparticles are efficient to remove heavy metals, such as uranium [56], hexavalent chromium ions [59,60], copper(II), and lead(II) ions [52], from aqueous systems. Maghemite nanoparticles are so promising in this field that they can clean up contaminated water to drinking water standards [60].

Like hematite nanoparticles, maghemite nanoparticles can also be used in fertilizer formulations. In contrast to chelated irons, employment of maghemite nanoparticles in plant fertilizers resulted in more improved agronomic properties such as growth rate of leaves and chlorophyll content [57]. Also, maghemite nanoparticles can improve plants' abiotic stress tolerance. Delivery of maghemite nanoparticles by irrigation in a nutrient solution to plants resulted in a significant reduction of hydrogen peroxide and malondialdehyde formation. These effects were discussed as nanozyme properties of maghemite nanoparticles [57].

Maghemite nanoparticles have been approved by the FDA to be employed in medical and pharmaceutical sciences [61,62]. These nanoparticles can be used for theranostic applications [63]. Nanostructures of maghemite can illustrate the high values of magnetic saturation (near or equal to magnetite nanoparticles) that makes them ideal for biomedical magnetic applications, such as magnetic labeling, magnetically guided deliveries, and hyperthermia therapies [51,63-65]. For instance, it has been shown that by using $10 \mathrm{~nm}$ maghemite nanoparticles an increase in the temperature of up to $\sim 50{ }^{\circ} \mathrm{C}$ is possible [51]. Maghemite nanoparticles are also a promising candidate for the fabrication of dual functional nanostructures. Fluorescent magnetic nanoparticles are one of them. In an experiment rhodamine isothiocyanate (RITC) is covalently encapsulated within maghemite nanoparticles and used for cell labeling. These nanostructures were found to be $\mathrm{pH}$ sensitive and introduced as a $\mathrm{pH}$ sensor for animal tissues and cell compartments [66]. In another experiment rhodamine was used for labeling a maghemite-albumin nanohybrid to combine targeting by the iron-acquisition pathway and photothermal therapies [67].

Maghemite nanoparticles can be employed in magnetofection techniques. Nanoparticles with efficient coatings, such as dendrimers, can couple fragments of DNA and take them into the cell under magnetic stimulus [68].

Drugs can also be delivered by these nanoparticles. In an attempt to fabricate a potential drug carrier, maghemite nanoparticles were functionalized with divergent molecules, such as human serum albumin (HSA), aminobenzoic acid, poly (ethylene imine) (PEI), and poly (ethylene oxide)-block-poly(glutamic acid) (PEO-PGA) [69-71]. Maghemite nanoparticles were also employed for the fabrication of multi stimuli-responsive smart nanogels. By combining thermo-responsive polymers, such as poly (vinyl alcohol)- $b$-poly( $N$-vinylcaprolactam) copolymers with maghemite nanoparticles, an innovative drug delivery system was obtained that is glucose-, pH-, thermo-, and magnetic-responsive. In addition, the magnetic properties of the maghemite nanoparticles make nanogel effective for magnetically-induced heating and magnetic resonance imaging (MRI) performance [72].

Maghemite nanoparticles can be used as a high sensitivity magnetic biosensor. In an experiment, it has been shown that, based on the giant magneto-impedance (GMI) effect, MAT-LyLu cells that grow in the presence of $0.1 \mathrm{mg} / \mathrm{mL}$ nanoparticles for $24 \mathrm{~h}$ make detectable modifications in the magnetic field at $1 \mathrm{MHz}$ frequency [65].

Beside all the mentioned applications, maghemite nanoparticles have gained applications in tissue engineering and biologic scaffolds preparation. The inclusion of these nanoparticles in the scaffolds' 
polymer network resulted in the significant improvement in physical and chemical characteristics of the prepared scaffolds. It has been shown that gradual increase of nanoparticle concentration in the polymer network significantly increases the polymer's hydrophilicity, water swelling, Young modulus (mechanical stiffness), effective viscosity, and negative value of electrical potential [73,74]. Maghemite nanoparticles also improve biologic properties of the scaffolds. Polymers imbedded with maghemite nanoparticles pose increased biocompatibility and cell adhesion index [73]. It has been shown that addition of maghemite nanoparticles to the scaffolds can increase initial cell adhesion by 1.4-fold, enabling earlier cellular proliferation confluence [74]. In some cases, doping with maghemite nanoparticles provides scaffolds with specific advantages for particular tissues. For instance, the application of these nanoparticles in scaffolds for bone repair and regeneration resulted in higher mineral induction [74]. In regard to skin repair, nanoparticle-doped scaffolds provide a higher cell proliferation rate for human skin fibroblast cells [75]. Maghemite nanoparticles were also used for tissue engineering a heart valve to obtain the required properties of an aortic heart valve. Fabricated materials using this technology are desirable scaffolds for human aortic smooth muscle cells migration and proliferation. In addition, these scaffolds provide a mutual adaption in terms of clotting time and hemolysis percent [76].

$\varepsilon-\mathrm{Fe}_{2} \mathrm{O}_{3}$

$\varepsilon-\mathrm{Fe}_{2} \mathrm{O}_{3}$ has an orthorhombic crystal system and shows properties between the alpha and gamma phases [32,77]. The $\varepsilon$-polymorph of $\mathrm{Fe}_{2} \mathrm{O}_{3}$ is unique due to its significant ferromagnetic resonance and coupled magnetoelectric features that cannot be found in any other phases [78]. This compound is metastable and at temperatures from $500{ }^{\circ} \mathrm{C}$ to $750{ }^{\circ} \mathrm{C}$ it turns into hematite (alpha phase). The preparation of the pure epsilon phase is also very challenging due to the contamination with alpha and gamma phases. There are some techniques to achieve a high proportion of epsilon phase [79]. However, the optimal reaction condition to achieve single-phase $\varepsilon-\mathrm{Fe}_{2} \mathrm{O}_{3}$ remains as a challenge for the future [78]. Recent studies have shown that this compound was used in the glazing of ceramics in ancient China [20]. Rod-shaped $\varepsilon-\mathrm{Fe}_{2} \mathrm{O}_{3}$ with a large coercive field were used in a mesoscopic ferrite bar magnet which can be used as a probe in magnetic force microscopes [80].

Zeta- $\mathrm{Fe}_{2} \mathrm{O}_{3}\left(\zeta-\mathrm{Fe}_{2} \mathrm{O}_{3}\right)$

As mentioned in detail previously, there are four well-known polymorphs for ferric oxide $\left(\alpha-\mathrm{Fe}_{2} \mathrm{O}_{3}, \beta-\mathrm{Fe}_{2} \mathrm{O}_{3}, \gamma-\mathrm{Fe}_{2} \mathrm{O}_{3}\right.$, and $\left.\varepsilon-\mathrm{Fe}_{2} \mathrm{O}_{3}\right)$, which are similar in chemical structure but differ in crystal structures and, hence, physical properties However, in 2015, via synchrotron X-ray diffraction experiments, a new phase was introduced for ferric oxide. It evolved from cubic $\beta-\mathrm{Fe}_{2} \mathrm{O}_{3}$ during a high pressure (above $30 \mathrm{GPa}$ ) treatment and was termed zeta- $\mathrm{Fe}_{2} \mathrm{O}_{3}\left(\zeta-\mathrm{Fe}_{2} \mathrm{O}_{3}\right)$. After pressure release the structure was retained and was stable at an ambient atmosphere. The structure was also stable at high pressures up to $70 \mathrm{GPa}$, which is above the pressures that induced phase transfer in other ferric oxide phases. This structure shows antiferromagnetic properties with $\sim 69^{\circ} \mathrm{K}$ Neel transition temperature. The discoverers claimed that this novel phase may have unique physicochemical properties that would lend it particular applications [81].

\subsubsection{Hydrous Ferric Oxide (Ferrihydrite)}

Hydrous ferric oxide or ferrihydrite is one of the well-known iron compounds with a $5 \mathrm{Fe}_{2} \mathrm{O}_{3} \cdot 9 \mathrm{H}_{2} \mathrm{O}$ chemical formula. However, there are also other reported formulas such as $\mathrm{Fe}_{5} \mathrm{HO}_{8} \cdot 4 \mathrm{H}_{2} \mathrm{O}$ and $\mathrm{Fe}_{2} \mathrm{O}_{3} \cdot 2 \mathrm{FeO}(\mathrm{OH}) \cdot 2 \cdot 6 \mathrm{H}_{2} \mathrm{O}[82,83]$. The indeterminate chemical formula of ferrihydrite is due to the variability of the content of combined water. Ferrihydrite has a hexagonal crystal system (hcp) and a spherical habit crystal. Based on the constitutive crystallites, ferrihydrite can be considered between two diffraction end-crystalline structures which are described as two- or six-line ferrihydrite. This nomination is based on the number of scattering bands in their X-ray diffraction patterns. 
It is interesting that ferrihydrite can just be found in the nature as nanocrystals in a dark brown or reddish brown color $[20,83]$. It is a widespread mineral on the Earth and can be found in soil and sediments of hot springs, marine environments, and fresh waters. In these environments ferrihydrite nanostructures precipitate by the oxidation of aqueous $\mathrm{Fe}(\mathrm{II})$ solutions that contain dissolved organic matter. The oxidation occurs at neutral $\mathrm{pH}$ and it is obvious that presence of organic compounds significantly affects the crystallinity of the resulted nanostructures $[84,85]$. Ferrihydrite can be mineralized as nanoparticles in the ferritin protein of animals, plants, and microorganisms, where it is utilized in intracellular iron storage [86]. It has been shown that crystalline and amorphous ferrihydrite nanoparticles in the size range of 3-6 $\mathrm{nm}$ can be assembled within ferritin [87]. Some microbial cells are also able to mineralize ferrihydrite nanostructures on the cell surface. The structure is mostly nanostructured polysaccharide-iron hydrogel and produced under microaerophilic conditions. Nanostructures which are produced by the bacterium Klebsiella oxytoca are one of the well-known and studied mineralize ferrihydrite nanostructures. This iron reducing bacterium (FeRB) is able to ferment ferric citrate under microaerophilic or anaerobic conditions and produces a Fe(III)-hydrogel [88-91]. Other bacterial cells, such as Staphylococcus warneri, Xanthomonas campestris, and Ralstonia sp., were also reported to be able to fabricate an $\mathrm{Fe}(\mathrm{III})$-binding exopolysaccharide and develop polysaccharide-iron nanostructures [92-94]. Synthetic ferrihydrite nanoparticles can also be prepared chemically. The reaction can be performed at ambient atmosphere by adding an alkaline solution $(\mathrm{NaOH})$ to the solution of ferric ions (e.g., ferric nitrate, $\mathrm{Fe}\left(\mathrm{NO}_{3}\right)_{3} \cdot 9 \mathrm{H}_{2} \mathrm{O}$, or ferric chloride, $\mathrm{FeCl}_{3} \cdot 6 \mathrm{H}_{2}$ ) under constant stirring $[95,96]$.

Both synthetic and biologic ferrihydrite nanostructures exhibit weak magnetic (paramagnetic) behavior. Low magnetic response beside good contrasting properties and biostability make the ferrihydrite a valuable contrasting agent for MRI imaging [97]. However, there are some techniques to improve the magnetic moment of ferrihydrite nanoparticles. It has been shown that the heat treatment of ferrihydrite nanoparticles at low temperatures (about $160{ }^{\circ} \mathrm{C}$ ) enhances the average magnetic moment of biosynthesized nanoparticles. It is claimed that an enhanced in magnetic moment can be due to the partial agglomeration of nanoparticles throughout heat treatment process [98].

Ferrihydrite nanoparticles have gained applications in environmental remediation activities. These particles can be employed to remove mineral contaminants such as $\mathrm{Pb}$ (II), $\mathrm{Cd}(\mathrm{II})$, $\mathrm{Cu}(\mathrm{II}), \mathrm{Zn}(\mathrm{II})$, phosphate, and arsenate from aqueous solutions [99,100]. In the case of organic contaminants, ferrihydrite nanoparticles are known to effectively improve the bioremediation activities. Microorganisms play the main role in this regard and ferrihydrite nanoparticles can enhance microbial degradation of a wide range of contaminants [101]. In recent attempts scientists tried to inject a colloidal ferrihydrite in the subsurface to create reactive zones and promote biodegradation reactions [101]. There are also some attempts to enhance particles' mobility in the soil column via polymer coatings as a surface engineering strategy or post flushing with particle-free electrolyte solutions [101,102]. The injection of ferrihydrite nanoparticles in the soil column is not just profitable for the soil microorganisms; the soil that is treated with ferrihydrite nanoparticles is even more beneficial for plants. It has been shown that soil enrichment with ferrihydrite nanoparticles enhances the growth and chlorophyll content in the maize seedlings [103].

\subsection{Ferrous Ferric Oxide $\left(\mathrm{Fe}_{3} \mathrm{O}_{4}\right)$}

Ferrous ferric oxide is well known as magnetite and its name is taken from the Greek word "magnet". Its IUPAC (International Union of Pure and Applied Chemistry) name is iron (II, III) oxide, and its common chemical name is ferrous-ferric oxide. It has two iron (III) and one iron (II) in combination with four oxygen. The structural formula of $\mathrm{Fe}_{3} \mathrm{O}_{4}$ is shown in Figure S1. Magnetite has a crystal cubic-hexoctahedral system with an octahedral habit crystal. It has a black appearance with a metallic opaque sheen. This combination is fragile and has caught the attention of researchers because of its outstanding properties and has therefore has been thoroughly studied. Magnetite is ferrimagnetic and can be employed as a permanent magnet [20,32]. 
It is interesting that magnetite shows superparamagnetic qualities in the nanometer range ( 1 to 100 nanometers). This means that nanoscale magnetite fails to maintain magnetization after removal of the external magnetic field. This unique property makes magnetite nanoparticles one of the most employed nanostructures in technology, science, and especially in medicine. Wide applications of magnetite nanoparticles have led to the development of various methods for their synthesis. Some of the common methods of magnetite nanoparticle synthesis are pyrolysis of organometallic compounds, polyol process, micro emulsion, hydrothermal synthesis, sol-gel, and coprecipitation [104]. Coprecipitation is the most commonly employed technique. In this method, magnetite nanoparticles are produced using bivalent and trivalent hydrated salt ions in the presence of a strong base under controlled atmosphere. The chemical reaction is as provided in Equation (4).

$$
2 \mathrm{Fe}^{+3}+\mathrm{Fe}^{+2}+8 \mathrm{OH}^{-} \rightarrow \mathrm{Fe}_{3} \mathrm{O}_{4}+4 \mathrm{H}_{2} \mathrm{O}
$$

It is fair to mention that magnetite nanoparticles are the most studied and employed iron-based nanostructures. These particles have gained myriad divergent applications in engineering, such as data storage and transfer [105], the rising up and the aggregation of activated sludge [106], heavy metal absorbents [107,108], nanocatalysts [109], and various others. In addition to the various engineering applications of magnetite nanoparticles, plenty of studies were also performed for the medical application of magnetite nanoparticles in drug delivery, magnetic resonance imaging (MRI), hyperthermia therapy, and immunoassay $[110,111]$. In order to employ magnetic iron oxide nanoparticles in medical applications, they are usually coated with biocompatible organic or inorganic molecules, such as silica, amino acids, lipoamino acids, carbohydrates, proteins, and polymers [112-122]. Biocompatible magnetite nanoparticles have also been widely used in biological sciences for magnetic labeling and the magnetic separation of the cells and biomolecules (e.g., nucleic acids, enzymes, and antibodies) [123-136]. These nanoparticles gained some applications to increase the performance and addressing the defects of fermentation industries. Magnetite nanoparticles can increase the performance of microbial cells and make high performance cells. It showed that magnetite nanoparticles can increase the permeability of the cell membrane toward improvement in mass transfer and increasing the cell functions $[123,137,138]$. On the other hand, certain concentrations of magnetite nanoparticles can affect biofilm formation by microbial cells which is a major problem of the fermenters $[139,140]$. A recent study showed that by using magnetite nanoparticles in a fermentation period, valuable industrial strains can be protected from potential phage infections [141].

It is interesting that living creatures employ magnetite nanoparticles for navigation. Magnetotactic bacteria are Gram-negative bacteria that are able to build specialized magnetite nanostructures. Members of this bacterial family are able to fabricate magnetosome nanostructures that are biogenerated magnetite nanocrystals engulfed by a phospholipid bilayer. Magnetosomes are arranged in a line in the cytoplasm of bacteria and act as a compass needle to provide the ability of magnetotaxis for the cell [142]. Magnetosomes can be in diverse morphologies and it has been shown that environmental conditions have an immense effect on their morphology [143]. Biogenic magnetite nanoparticles are not restricted to the bacterial realm and there are obvious reports for the presence of these nanostructures in migratory and non-migratory animals. It has been shown that, like arrangement of magnetosome in the bacterial cytoplasm, magnetic nanoparticles are arranged in short or long chains in the ethmoid and lateral ethmoid bones of migratory and non-migratory fishes [144]. The chains of magnetic nanoparticles were also reported in the plants. Magnetic nanoparticles are located in the form of chains in the wall of the phloem sieve tubes (i.e., the vascular tissue of plants) [145]. Interestingly, magnetite nanoparticles have been identified in human tissues (e.g., brain, meninges, heart, liver, spleen, and cervical skin) [146]. In addition, human stem cells are able to degrade and synthesize magnetic nanoparticles [147]. 


\section{Ferric Oxide-Hydroxide (Ferric Oxyhydroxide)}

Ferric oxyhydroxide is composed of iron, oxygen, and hydrogen with the $\mathrm{FeO}(\mathrm{OH})$ chemical formula $(\mathrm{O}=\mathrm{Fe}-\mathrm{OH}$, Figure $\mathrm{S} 1)$. In aqueous matrixes, ferric ions can hydrolyze to some extent and produce ferric oxyhydroxide. As shown in Equation (5), this hydrolysis reaction produces protons and, to some extent, makes the environment acidic. Ferric oxyhydroxide is usually encountered as hydrated forms with the $\mathrm{FeO}(\mathrm{OH}) \cdot \mathrm{nH}_{2} \mathrm{O}$ general formula (see the Section 4.2) and anhydrous ferric oxyhydroxide. These two forms are discussed in the following sections.

$$
\mathrm{Fe}(\mathrm{III})+2 \mathrm{H}_{2} \mathrm{O} \rightarrow \mathrm{FeO}(\mathrm{OH})+3 \mathrm{H}^{+}
$$

\subsection{Anhydrous Ferric Oxyhydroxides}

Like ferric oxide, anhydrous ferric oxyhydroxide can be found in four different polymorphs, denoted as the $\alpha, \beta, \gamma$, and $\delta$ phases. Different phases are distinguished by their distinct crystalline structure [20].

\subsubsection{Goethite $(\alpha-\mathrm{FeOOH})$}

Goethite is the main component of iron rust and is also the main compound of bog iron ores. In recent years, this mineral has benn used as iron ore and known as brown iron ore. Goethite is an antiferromagnetic mineral [148]. It has an orthorhombic crystal system and its crystal habitat is usually either needle, star, or hexagonal $[20,148]$. Its color in the crystalline state is dark brown or black and yellow. When powder, it is semi-transparent to opaque.

Recent investigations revealed that nanostructures of goethite can be formed in nature. By cryogenic Fe MÖssbauer spectroscopy studies it was discovered that in the marine and lacustrine environments the ferric oxyhydroxide phase is the nanogoethite [149]. The laboratory synthesis of goethite nanoparticles is usually performed by using ferric nitrate $\left(\mathrm{Fe}\left(\mathrm{NO}_{3}\right)_{3} \cdot 9 \mathrm{H}_{2} \mathrm{O}\right)$ or ferric chloride hexahydrate $\left(\mathrm{FeCl}_{3} \cdot 6 \mathrm{H}_{2} \mathrm{O}\right)$ as an iron precursor. In this order a basic solution, mostly sodium hydroxide $(\mathrm{NaOH})$, is added to the iron solution with continuous stirring until a clear solution of yellowish-brown color is formed. This yellowish-brown precipitate is ferrihydrite and needs to age to goethite $[96,150]$. The aging process is done at high temperatures, about $60-100{ }^{\circ} \mathrm{C}[96,151,152]$. The speed of the base addition is a critical point in the process and is inversely proportional to the resulting particles' specific surface area. It is shown that by varying the rate of base addition from $1 \mathrm{~mL} / \mathrm{min}$ to $10 \mathrm{~mL} / \mathrm{min}$ the obtained specific surface area is reduced from $101 \pm 5 \mathrm{~m}^{2} / \mathrm{g}$ to $64 \pm 2 \mathrm{~m}^{2} / \mathrm{g}$ [96]. The major problem with these techniques is that the produced nanoparticles are not uniform in shape and size. Recent experiments indicated that this problem can be solved by controlled synthesis reactions. These reactions are based on the fact that presence of additional molecules, such as carbohydrates, can control the crystals' growth pattern. It has been shown that such compounds can drive the reaction to induce isotropic growth of goethite nanocrystals [150].

High quality goethite is rare and usually polished to be used in making jewelry [20]. From an industrial standpoint, goethite is among the main pigments (brown ochre; a yellowish-brown pigment) which has been used since ancient times. Goethite nanoparticles have gained some environmental applications and are used to remove metallic cation pollutants, such as arsenic and chromium [152-154]. These nanoparticles are also used as an absorbent for the removal of fluoride from contaminated waters [83]. Surface modification studies were also performed to enhance the nanostructures' stability and mobility in porous media. Humic acid is reported to be efficient in this regard. However, the major drawback is aggregation in the presence of divalent cations, e.g., calcium and magnesium ions, which is due to complexation phenomena related to the interaction of divalent cations with humic acid [155].

Goethite nanoparticles are able to quench free radicals. This property can be used to improve the oxidative stability of commercial products to enhance the storage time. For instance, gasoline oxidation is a factor that significantly decreases the gasoline storage time. A study on the gasoline 
induction period indicated that goethite nanoparticles can inhibit gasoline oxidation and significantly elongate the induction period of the commercial gasoline [156].

\subsubsection{Akaganeite $(\beta-\mathrm{FeOOH})$}

The name of this compound has been taken from the Akagan mine in Japan. It is an antiferromagnetic mineral and has a monoclinic crystal system with hexagonal, bar-like, star-shaped, and prismatic crystals [157]. Its appearance has a tan-brown color with a metallic sheen. This mineral has been found in different parts of Earth as well as in the rocks from the Moon. This mineral can be found in corrosion of iron and hot springs that contain chloride [158]. Although akaganeite is known as one of the anhydrous forms of $\mathrm{FeOOH}$, in chloride-containing environments. In such conditions, chloride takes part in the structure and so the exact structure would be $\mathrm{FeO}_{0.833}(\mathrm{OH})_{1.167} \mathrm{Cl}_{0.167}$ [158]. In fact, it is composed of an iron oxyhydroxide framework with tunnels, hollandite channels, that is filled with chloride ions $[157,158]$.

The nanostructure of akaganeite is mostly formed in nanorods and can be synthesized by hydrolysis of an iron chloride solution. The reaction is performed at high temperatures, about $80^{\circ} \mathrm{C}$, and usually in the presence of surfactants, e.g., poly (ethylene oxide) (PEO) or polymers (e.g., polyethyleneimine) as a capping agent and structure director to control the particle size distribution and particles shape [159-161]. Control over the particles' size is possible by varying the concentration of the capping agent. In fact, smaller nanorods can be obtained by increasing the concentration of capping agent [159].

Akaganeite has aroused widespread interest as a new generation of adsorbent material owing to its outstanding uptake capacity for toxic anions and cations [157,158,162]. Akaganeite ion exchange capability strongly depends on the hydroxyl groups located outside of the hollandite channels [163]. Formation of oriented aggregations is a key feature of the akaganeite nanorods [161,164]. New synthesis techniques have been developed to fabricate mesoporous akaganeite nanorods with increased specific surface area and hierarchical scaffold structure which is formed through the nano-rods' aggregation [161]. These structures can provide even more uptake capability for akaganeite nanorods. Akaganeite nanorods can also be used as catalyst material. Among various iron oxide and iron oxide hydroxide nanostructures, akaganeite nanorods are the most effective catalysts for the reduction of 4-nitrotoluene using hydrazine hydrate as a reducing agent [83]. One of the promising applications of akaganeite nanorods is in the fabrication of magnetite nanorods. Converting akaganeite nanorods into magnetite is a common approach for the synthesis of ellipsoidal magnetite nanoparticles. This conversion can be performed through a reduction reaction by using a chemical reducing agent, such as hydrazine (Equation (6)) [160].

$$
12 \beta-\mathrm{FeOOH}+\mathrm{N}_{2} \mathrm{H}_{4} \rightarrow 4 \mathrm{Fe}_{3} \mathrm{O}_{4}+8 \mathrm{H}_{2} \mathrm{O}+\mathrm{N}_{2}
$$

\subsubsection{Lepidocrocite $(\gamma-\mathrm{FeOOH})$}

Lepidocrocite is also called esmeraldite or hydrohematite. It is thermodynamically metastable and based on the aqueous condition, undergoes a phase transition to a more stable iron oxide structure $[165,166]$. This iron combination has anti-ferromagnetic properties. It can be formed in crystalline or amorphous structures from iron oxidation phenomena, such as atmospheric oxidation or sea corrosion [167]. Its crystal system and structure are orthorhombic, and its crystal habit is normally string-shaped [168]. Its appearance has a ruby red to orange-brown color, has a semi-metallic sheen, and is found in rocks, soil, and rust. It has transparent crystals that form thin sheet-like structures [169]. This fine appearance captures attention of jewelry designers and takes lepidocrocite to the jewelry industry.

Nanoscale lepidocrocite can be formed by the oxidation of zero-valent iron nanostructures (ZVINs) in oxygenated aqueous matrixes [170]. By the oxidation of ZVINs, ferrous ions diffuse out of the structure and an oxidized layer will form on the zero-valent core. The complete oxidation of zero-valent core resulted in the collapse of the core-shell structure and complete variations in the structure and 
composition. The resulting structure was a reddish-brown powder of nanosheets and nanoneedles which are characteristic morphology of iron oxide nanostructures $[170,171]$. In another approach, lepidocrocite nanoparticles can be fabricated by adding sodium hydroxide $(\mathrm{NaOH})$ to a solution of ferric ions to reach a $\mathrm{pH}$ of $\sim 6[167,168,172]$.

Like other iron-based nanostructures, nanoscale lepidocrocite has gained applications as adsorbent and catalyst. It can be employed to remove heavy metals (e.g., chromium and uranium) and metal complex dyes (e.g., Lanacron brown S-GL which is known as Acid Brown 298, LBS-GL) $[167,172,173]$. These nanostructures are able to catalyze degradation reactions. For instance, lepidocrocite nanoparticles were employed for the degradation of carbon tetrachloride $\left(\mathrm{CCl}_{4}\right)$ and it showed that the compound was degraded in a second-order reaction [171]. From a microbiological point of view, it has been shown that iron reducing bacteria (IRB) can employ nanoscale lepidocrocite as an electron acceptor when special compounds (e.g., hydrogen, formate, pyruvate, serine, lactate, ore $\mathrm{N}$-acetylglucosamine) are utilized as electron donors [174].

\subsubsection{Feroxyhyte $(\delta-\mathrm{FeOOH})$}

Feroxyhyte has a hexagonal closed-packed crystal system and is essentially a planar antiferromagnet $[175,176]$. It can be found naturally as yellowish-brown deposits in iron-manganese nodules at high pressure environments, such as a very deep ocean and gleysol. However, by exposure to surface environment or aerated conditions, it converts to goethite [177]. It is the only phase of anhydrous ferric oxide-hydroxide that has significant magnetic properties at room temperature $[178,179]$. Feroxyhyte nanoparticles are usually synthesized by the rapid oxidation of ferric hydroxide $\left(\mathrm{Fe}(\mathrm{OH})_{2}\right)$, whereas hydrogen peroxide and the resulting nanostructures can be in plate, needle, or sphere morphologies [176,178,180-182]. In addition, magnetite $\left(\mathrm{Fe}_{3} \mathrm{O}_{4}\right)$ nanoparticles can be used as a precursor to fabricate feroxyhyte nanoparticles. In this technique, magnetite nanoparticles are rapidly oxidized in the air [178]. Irradiation-based techniques were also developed to fabricate these nanoparticles [180]. In these approaches $\gamma$-irradiation is used to reduce ferric ions to ferrous and then a white suspension of ferric hydroxide is resulted. The resulting ferric hydroxide can be oxidized rapidly while coming into contact with atmospheric oxygen [180].

Nanostructures of feroxyhyte have a promising potential in environmental sciences and wastewater treatment. These particles can activate hydrogen peroxide to generate reactive oxygen species (ROS) which are effective in degradation of organic molecules [181]. Feroxyhyte nanoparticles can also eliminate inorganic pollutants. It has been shown that mesoporous feroxyhyte nanoparticles and ferrous ions have a synergistic action for phosphate immobilization. Hydroxyl groups on the nanoparticles and in-situ generated ferric ions were found to promote phosphate immobilization. This $\delta$-FeOOH/Fe(II) synergistic system can reached about $94 \%$ removal efficiency at acidic $\mathrm{pH}$ [183]. Doping of nanostructures with foreign metal ions, such as cupper and manganese, is another approach to enhance the catalytic and adsorbent properties of feroxyhyte nanoparticles [178,179,184]. These nanostructures are applicable in batch and continuous flow models to remove heavy metal (e.g., arsenic, cadmium, mercury, and nickel) pollutants from drinking water $[185,186]$. Feroxyhyte can be used as a coating for other nano-adsorbents, such as maghemite ( $\gamma$-Fe2O3) nanoparticles, to improve their stability and recovery capacity. It has been shown that maghemite nanoparticles with various ratios of feroxyhyte coating have different potentials for chromate (VI) removal, and the optimal mass ratio of coating to core is 1.0 [187].

Feroxyhyte nanoparticles can be used as a photocatalyst for water splitting and hydrogen generation. Besides common nano size features such as the small particle size and high surface area, these nanoparticles have a small band gap energy and mesoporous structure that make feroxyhyte nanoparticles a suitable photocatalyst [188]. Like what we have in the remediation activities, foreign metal doping can also increase the photocatalytic activity of feroxyhyte nanoparticles. Nickel ions $\left(\mathrm{Ni}^{2+}\right)$ can be used to increase the conductivity and charge transfer in the particles. By loading $\mathrm{Ni}(\mathrm{OH})_{2}$ 
on the surface of the resulting structure, charge separation will also improve. These modifications significantly enhance the photocatalytic activity of feroxyhyte nanoparticles [189].

Feroxyhyte nanoparticles behave superparamagnetically or ferromagnetically at ambient temperature [176,182]. Therefore, these particles can be considered in technical, medical, and biomedical practices as an alternative for previously employed magnetic nanoparticles. Experimental evidences showed that feroxyhyte nanoparticles can release heat under an alternative magnetic field and the heat production can be controlled by changing the mass of nanoparticles [182].

\subsubsection{Schwertmannite}

In 1994 schwertmannite was introduced as a novel iron oxyhydroxysulphate from the Pyhäisalmi sulphide mine, Province of Oulu, Finland. It was found in ochreous precipitates from acid, sulphate-rich waters [190]. Schwertmannite has a structure similar to akaganeite, the only difference being that schwertmannite has sulfate ions instead of chloride ions so it is called iron oxyhydroxysulfate mineral with the chemical formula of $\mathrm{Fe} 8 \mathrm{O} 8(\mathrm{OH}) 8-2 \mathrm{x}(\mathrm{SO} 4) \mathrm{x} \cdot \mathrm{nH} 2 \mathrm{O}(1 \leq \mathrm{x} \leq 1.75)[191,192]$. It is poorly crystalline nanometric material with tetragonal crystal system and paramagnetic behavior [193]. It appears as an opaque yellowish-brown and has a fibrous morphology under the electron microscope [190,191].

In nature, schwertmannite nanocrystals were formed through the oxidation of ferrous ions and subsequently ferric ions precipitation. Synthetic schwertmannite nanoparticles can also be fabricated by the chemical oxidation of ferrous ions. Usually ferrous ions are provided from an $\mathrm{FeSO}_{4}$ solution and hydrogen peroxide is used as an oxidizing agent (Equation (7)). Precipitation occurred by hydrolysis of the resulting ferric ions. Ferric ions first form a complex intermediate with water molecules and then, at high concentrations of sulfate ions $\left(\mathrm{SO}_{4}{ }^{2+}\right)$, transform into schwertmannite. The total reaction is illustrated in Equation (8) [192].

$$
\begin{gathered}
2 \mathrm{Fe}^{2+}+\mathrm{H}_{2} \mathrm{O}_{2}+2 \mathrm{H}^{+} \rightarrow 2 \mathrm{Fe}^{3+}+2 \mathrm{H}_{2} \mathrm{O} \\
8 \mathrm{Fe}\left(\mathrm{SO}_{4}\right)+2 \mathrm{O}_{2}+(4+\mathrm{x}) \mathrm{H}_{2} \mathrm{O} \rightarrow \mathrm{Fe}_{8} \mathrm{O}_{8}(\mathrm{OH})_{x}\left(\mathrm{SO}_{4}\right)_{\mathrm{y}}+\left(8-\mathrm{y}^{3} \mathrm{SO}_{4}{ }^{2+}+2(8-\mathrm{y}) \mathrm{H}^{+}\right.
\end{gathered}
$$

Biosynthesis (biogenic fabrication) is another technique for the fabrication of schwertmannite nanostructures. It is dependent on the biological ferrooxidation of ferrous ions by iron oxidizing microorganisms that are able to oxidize ferrous ions or elemental sulfur as a source of energy. These organisms can precipitate nano-sized schwertmannite at ambient temperature and acidic $\mathrm{pH}(\sim 2-3)$ [194]. Acidithiobacillus ferrooxidans is the most known and studied bacteria in this family [195].

Schwertmannite was found to have considerable potential as an absorbent material, which is applicable for water treatment and soil remediation purposes. It has a promising potential to remove both mineral (e.g., arsenic, chromium, antimony, and fluoride) and organic contaminants [192]. Song et al. (2018) compared the characteristic features of chemically synthesized and biogenic schwertmannite nanostructures that are important for remediation purposes [196]. They show that chemical synthesis can fabricate more schwertmannite than biogenic methods. But biogenic methods provide larger nanoparticles with larger specific surface area. From a surface morphology point of view, chemically synthesized particles have a smooth surface, while the surface of the biogenic particles is chestnut shell-like with higher saturated adsorption capacity [196]. In addition, biogenic schwertmannite has a higher chemical stability. Synthetic schwertmannite is more sensitive to the aging process and conversion to the goethite [197]. Key features of the biogenic nanoparticles can even be improved by a simple heating. Heating up to $250{ }^{\circ} \mathrm{C}$ resulted in the significant increase in the particles' porosity, specific surface area, and efficiency for contaminants removal [198]. Biofabrication of schwertmannite has a critical point; adherence of prepared nanostructures to the reactor wall during the biosynthesis process resulted in deterioration of particles' structural characteristics. To eliminate the adhered schwertmannite, Zhang et al. introduced additional schwertmannite into the reactor 
system prior to schwertmannite biosynthesis. They show that by doing so, all biogenic schwertmannite nanostructures are in a suspended form [199].

\subsection{Hydrated Ferric Oxyhydroxides}

Ferric oxyhydroxide is usually encountered as hydrated forms with a $\mathrm{FeO}(\mathrm{OH}) \cdot \mathrm{nH}_{2} \mathrm{O}$ general formula. The monohydrate form of this compound is the most common form and is known as ferric hydroxide and its simplified formula is $\mathrm{Fe}(\mathrm{OH})_{3}$ (Figure S1f). For the first time it was reported from the Proprietary Mine at Broken Hill, New South Wales, Australia and called bernalite in homage to the British crystallographer J. D. Bernal (1901-1971) [200]. Bernalite is structurally related to perovskites (a calcium titanium oxide mineral, $\mathrm{CaTiO}_{3}$ ) and its small crystals, up to $3 \mathrm{~mm}$, occurs as flattened pyramidal to pseudo-octahedral with slightly concave faces. Due to goethite inclusions, the crystals can be transparent to opaque with pale green (bottle-green) color [200,201].

Bernalite nanoparticles can be transformed from goethite nanorods at alkaline $\mathrm{pH}(\sim 10)$ and in the presence of arsenate. Arsenate has a key role in the formation of bernalite and the abundance of bernalite is in direct relation with the arsenate concentration [202]. In the laboratorial experiments, ferric hydroxide can be easily obtained by increasing the $\mathrm{pH}$ of a ferric ions solution up to about 8 as in Equation (9) shows [203].

$$
\mathrm{Fe}(\mathrm{III})+3 \mathrm{OH}^{-} \rightarrow \mathrm{Fe}(\mathrm{OH})_{3}
$$

It can be a basic reaction to prepare a precursor for other iron-based nanoparticles. For instance, ferric hydroxide was used as a precursor for the generation of monodisperse ferromagnetic and superparamagnetic iron oxide nanoparticles [204]. In a similar manner, controlled dehydration of ferric hydroxide resulted in $\mathrm{Fe}_{2} \mathrm{O}_{3}$ [205]. In a novel approach, Thuy et al. (2014) employed the reaction for the fabrication of colloidal ferric hydroxide to remove heavy metals from water. They combined the coprecipitation of ferric hydroxide and flotation technique using gamma poly-glutamic acid ( $\gamma$-PGA) for collecting $\mathrm{Au}, \mathrm{Bi}, \mathrm{Co}, \mathrm{Cd}, \mathrm{Cu}, \mathrm{In}, \mathrm{Ir}, \mathrm{Mn}, \mathrm{Ni}, \mathrm{Pb}, \mathrm{Pd}, \mathrm{Pt}, \mathrm{Te}, \mathrm{Sb}, \mathrm{Rh}, \mathrm{Ru}$, and $\mathrm{Zn}$. To perform the precipitation reaction, they added a solution of sodium hydroxide to heavy metals contaminated water containing ferrous ions [206]. Coprecipitation of ferric hydroxide can also be performed in the presence of other nanoparticles, such as magnetite nanoparticles, and form a core-shell structure. Arefi et al. showed that the resulting core-shell nanostructure is applicable as a heterogeneous catalyst for the direct oxidative amidation of alcohols with amine hydrochloride salts [207].

\section{Iron Hydroxides}

Iron hydroxides can be found in two different structures as ferrous hydroxide and ferric hydroxide. Molecular structure of ferrous hydroxide is provided in Figure 1, and it can be denoted as $\mathrm{Fe}(\mathrm{OH})_{2}$ or $\mathrm{FeH}_{2} \mathrm{O}_{2}$. Basically, it is a nearly white substance, but by exposure to oxygen, ferrous ions are oxidized to ferric and provide a greenish to reddish-brown color of ferric hydroxide. Chemically, ferrous hydroxide is produced as a gelatinous precipitate when ferrous ions are exposed to an alkali, such as hydroxide salts or ammonium (Equation (10)). In the synthesis of ferrous hydroxide nanoparticles, the employed alkali has a significant effect on the shape and surface features of the resulted nanostructure. It was shown that ammonium derived the reaction to make nanospheres with a porous surface, while hydroxide salts (e.g., $\mathrm{NaOH}$ ) make smooth nanorods. It is obvious that the product is sensitive to the oxygen, and hence the reaction should be performed under an inert atmosphere [208].

$$
\mathrm{Fe}^{2+}+2 \mathrm{OH}^{-} \rightarrow \mathrm{Fe}(\mathrm{OH})_{2}
$$

Nanostructures of ferrous hydroxide are great activators for hydrogen peroxide to produce hydroxyl radicals. This potential provides the particles a Fenton-like catalyst property that can be employed to degrade organic pollutants as a Fenton-like activator of hydrogen peroxide [208]. The molecular structure of ferric hydroxide is provided in Figure 1. Ferric hydroxide was discussed in detail in Section 4.2. 
The content of this review was summarized in tabular format as Supplementary Material and provided in Table S1 for a quick overview.

\section{Conclusions}

Iron as a well-known element from the ancient time, retaining an outstanding position in the human life and culture. Due to its different valency and combining power with oxygen atoms and water molecules, it comes in a colorful variety of compounds with diverse chemical structures and physical appearances. In the recent years, by taking iron compounds to the nano realm, we can improve the iron to achieve unpresented properties and applications. In this review 19 different compounds of iron, from pure iron to combined forms of iron with oxygen and water, were investigated for their structures, properties, synthesis routes, and applications as nanomaterials. Nanostructures of iron can be prepared by simple chemical reactions and even in some cases these structures are achievable via biologic pathways or biochemical reactions. Provided data demonstrate that iron-based nanomaterials can be employed in medical, biomedical, industrial, engineering, environmental, and agricultural sceneries. The discovery of the potential applications of iron-based nanomaterials only in its emerging phase and there will be a huge amount of investigations in this regard in the future.

Supplementary Materials: The following are available online at http://www.mdpi.com/2227-9717/8/9/1128/s1, Figure S1: Molecular structures of iron compounds, $\mathrm{FeO}(\mathrm{a}), \mathrm{Fe}_{2} \mathrm{O}_{3}$ (b), $\mathrm{Fe}_{3} \mathrm{O}_{4}$ (c), $\mathrm{FeOOH}(\mathrm{d}), \mathrm{Fe}(\mathrm{OH})_{2}(\mathrm{e})$, and $\mathrm{Fe}(\mathrm{OH})_{3}(\mathrm{f})$, Table S1: A tabular summery of the data that provided in the main manuscript.

Author Contributions: Conceptualization, S.-M.T. and A.E.; Software, S.-M.T.; Data Curation, S.-M.T. and A.E.; Writing-Original Draft Preparation, S.-M.T., A.E., and M.Z.; Writing-Review \& Editing, S.-M.T., A.E., and A.B.; Visualization, S.-M.T. and A.E.; Supervision, A.E. and A.B.; Project Administration, A.E. and A.B.; Funding Acquisition, A.B. and A.E. All authors have read and agreed to the published version of the manuscript.

Funding: The APC was funded by The University of Waikato.

Acknowledgments: This work was financially supported by Shiraz University of Medical Sciences under a grant NO. 99-01-121-23506. The APC was funded by The University of Waikato, Hamilton 3240, New Zealand.

Conflicts of Interest: The authors declare no conflict of interest.

\section{References}

1. Iron Ore Mine Production by Country 2014-2018. Available online: https://www.statista.com/statistics/ 267380/iron-ore-mine-production-by-country/ (accessed on 30 March 2019).

2. Fan, M.; Yuan, P.; Chen, T.; He, H.; Yuan, A.; Chen, K.; Zhu, J.; Liu, D. Synthesis, characterization and size control of zerovalent iron nanoparticles anchored on montmorillonite. Chin. Sci. Bull. 2010, 55, 1092-1099. [CrossRef]

3. Xiaomin, N.; Xiaobo, S.; Huagui, Z.; Dongen, Z.; Dandan, Y.; Qingbiao, Z. Studies on the one-step preparation of iron nanoparticles in solution. J. Cryst. Growth 2005, 275, 548-553. [CrossRef]

4. dos Santos, F.S.; Lago, F.R.; Yokoyama, L.; Fonseca, F.V. Synthesis and characterization of zero-valent iron nanoparticles supported on SBA-15. J. Mater. Res. Technol. 2017, 6, 178-183. [CrossRef]

5. Ebrahiminezhad, A.; Zare-Hoseinabadi, A.; Berenjian, A.; Ghasemi, Y. Green synthesis and characterization of zero-valent iron nanoparticles using stinging nettle (Urtica dioica) leaf extract. Green Proc. Synth. 2017, 6, 469-475. [CrossRef]

6. Taghizadeh, S.-M.; Berenjian, A.; Taghizadeh, S.; Ghasemi, Y.; Taherpour, A.; Sarmah, A.K.; Ebrahiminezhad, A. One-put green synthesis of multifunctional silver iron core-shell nanostructure with antimicrobial and catalytic properties. Ind. Crop. Prod. 2019, 130, 230-236. [CrossRef]

7. Akbari, A.; Mohamadzadeh, F. New method of synthesis of stable zero valent iron nanoparticles (nZVI) by chelating agent diethylene triamine penta acetic acid (DTPA) and removal of radioactive uranium from ground water by using Iron nanoparticle. J. Nanostruct. 2012, 2, 175-181. [CrossRef]

8. Sun, Y.-P.; Li, X.-q.; Cao, J.; Zhang, W.-x.; Wang, H.P. Characterization of zero-valent iron nanoparticles. Adv. Colloid Interface Sci. 2006, 120, 47-56. [CrossRef] 
9. Üzüm, Ç.; Shahwan, T.; Eroğlu, A.E.; Hallam, K.R.; Scott, T.B.; Lieberwirth, I. Synthesis and characterization of kaolinite-supported zero-valent iron nanoparticles and their application for the removal of aqueous $\mathrm{Cu}^{2+}$ and $\mathrm{Co}^{2+}$ ions. Appl. Clay Sci. 2009, 43, 172-181. [CrossRef]

10. Wu, Y.-N.; Yang, L.-X.; Shi, X.-Y.; Li, I.-C.; Biazik, J.M.; Ratinac, K.R.; Chen, D.-H.; Thordarson, P.; Shieh, D.-B.; Braet, F. The selective growth inhibition of oral cancer by iron core-gold shell nanoparticles through mitochondria-mediated autophagy. Biomaterials 2011, 32, 4565-4573. [CrossRef]

11. Yang, L.-X.; Wu, Y.-N.; Wang, P.-W.; Huang, K.-J.; Su, W.-C.; Shieh, D.-B. Silver-coated zero-valent iron nanoparticles enhance cancer therapy in mice through lysosome-dependent dual programed cell death pathways: Triggering simultaneous apoptosis and autophagy only in cancerous cells. J. Mater. Chem. B 2020, 8, 4122-4131. [CrossRef]

12. Ebrahiminezhad, A.; Zare-Hoseinabadi, A.; Sarmah, A.K.; Taghizadeh, S.; Ghasemi, Y.; Berenjian, A. Plant-Mediated synthesis and applications of iron nanoparticles. Mol. Biotechnol. 2018, 60, $154-168$. [CrossRef] [PubMed]

13. Huang, R.; Wang, X.; Xing, B. Removal of labile arsenic from flooded paddy soils with a novel extractive column loaded with quartz-supported nanoscale zero-valent iron. Environ. Pollut. 2019, 255, 113249. [CrossRef] [PubMed]

14. Liu, H.; Li, P.; Yu, H.; Zhang, T.; Qiu, F. Controlled fabrication of functionalized nanoscale zero-valent iron/celluloses composite with silicon as protective layer for arsenic removal. Chem. Eng. Res. Des. 2019, 151, 242-251. [CrossRef]

15. Tso, C.-p.; Shih, Y.-h. Effect of carboxylic acids on the properties of zerovalent iron toward adsorption and degradation of trichloroethylene. J. Environ. Manag. 2018, 206, 817-825. [CrossRef] [PubMed]

16. Ertosun, F.M.; Cellat, K.; Eren, O.; Gül, Ş.; Kuşvuran, E.; Şen, F. Comparison of nanoscale zero-valent iron, fenton, and photo-fenton processes for degradation of pesticide 2, 4-dichlorophenoxyacetic acid in aqueous solution. SN Appl. Sci. 2019, 1, 1491. [CrossRef]

17. Shojaei, S.; Shojaei, S. Optimization of process variables by the application of response surface methodology for dye removal using nanoscale zero-valent iron. Int. J. Environ. Sci. Technol. 2019, 16, 4601-4610. [CrossRef]

18. Ji,H.; Zhu, Y.; Duan, J.; Liu, W.; Zhao, D. Reductive immobilization and long-term remobilization of radioactive pertechnetate using bio-macromolecules stabilized zero valent iron nanoparticles. Chin. Chem. Lett. 2019, 30, 2163-2168. [CrossRef]

19. Lee, C.; Kim, J.Y.; Lee, W.I.; Nelson, K.L.; Yoon, J.; Sedlak, D.L. Bactericidal effect of zero-valent iron nanoparticles on Escherichia coli. Environ. Sci. Technol. 2008, 42, 4927-4933. [CrossRef]

20. Cornell, R.M.; Schwertmann, U. The Iron OXIDES: Structure, Properties, Reactions, Occurrences and Uses; John Wiley \& Sons: Hoboken, NJ, USA, 2003.

21. Redl, F.X.; Black, C.T.; Papaefthymiou, G.C.; Sandstrom, R.L.; Yin, M.; Zeng, H.; Murray, C.B.; O’Brien, S.P. Magnetic, electronic, and structural characterization of nonstoichiometric iron oxides at the nanoscale. J. Am. Chem. Soc. 2004, 126, 14583-14599. [CrossRef]

22. Guntlin, C.P.; Ochsenbein, S.T.; WÖrle, M.; Erni, R.; Kravchyk, K.V.; Kovalenko, M.V. Popcorn-shaped $\mathrm{Fe}_{\mathrm{x}} \mathrm{O}$ (Wüstite) nanoparticles from a single-source precursor: Colloidal synthesis and magnetic properties. Chem. Mater. 2018, 30, 1249-1256. [CrossRef]

23. Martinez, A.I.; Garcia-Lobato, M.; Perry, D.L. Study of the properties of iron oxide nanostructures. In Research in Nanotechnology Developments; Barrañón, A., Ed.; Nova Science Publishers, Inc.: Hauppauge, NY, USA, 2009; Volume 19, pp. 184-193.

24. Strobel, R.; Pratsinis, S.E. Direct synthesis of maghemite, magnetite and wustite nanoparticles by flame spray pyrolysis. Adv. Powder Technol. 2009, 20, 190-194. [CrossRef]

25. Chen, C.-J.; Chiang, R.-K.; Lai, H.-Y.; Lin, C.-R. Characterization of monodisperse wüstite nanoparticles following partial oxidation. J. Phys. Chem. C 2010, 114, 4258-4263. [CrossRef]

26. Gheisari, M.; Mozaffari, M.; Acet, M.; Amighian, J. Preparation and investigation of magnetic properties of wüstite nanoparticles. J. Magn. Magn. Mater. 2008, 320, 2618-2621. [CrossRef]

27. Papaefthymiou, G.; Redl, F.; Black, C.; Sandstrom, R.; Yin, M.; Murray, C.; O’Brien, S. Hybrid magnetic nanoparticles derived from wüstite disproportionation reactions at the nanoscale. In ICAME 2005; Springer: Berlin/Heidelberg, Germany, 2006; pp. 239-245. [CrossRef]

28. Ahmadipour, M.; Rao, K.V.; Rajendar, V. Formation of nanoscale $\mathrm{Mg}_{(\mathrm{x})} \mathrm{Fe}_{(1-\mathrm{X})} \mathrm{O}(\mathrm{x}=0.1,0.2,0.4)$ structure by solution combustion: Effect of fuel to oxidizer ratio. J. Nanomater. 2012, 2012, 163909. [CrossRef] 
29. Chen, C.-J.; Chiang, R.-K.; Kamali, S.; Wang, S.-L. Synthesis and controllable oxidation of monodisperse cobalt-doped wüstite nanoparticles and their core-shell stability and exchange-bias stabilization. Nanoscale 2015, 7, 14332-14343. [CrossRef]

30. Situ, S.F.; Samia, A.C.S. Highly efficient antibacterial iron oxide@carbon nanochains from wustite precursor nanoparticles. ACS Appl. Mater. Interfaces 2014, 6, 20154-20163. [CrossRef]

31. Chavez-Galan, J.; Almanza, R. Solar filters based on iron oxides used as efficient windows for energy savings. Sol. Energy 2007, 81, 13-19. [CrossRef]

32. Campos, E.A.; Pinto, D.V.B.S.; Oliveira, J.I.S.d.; Mattos, E.d.C.; Dutra, R.d.C.L. Synthesis, characterization and applications of iron oxide nanoparticles-a short review. J. Aerosp. Technol. Manag. 2015, 7, 267-276. [CrossRef]

33. Lassoued, A.; Dkhil, B.; Gadri, A.; Ammar, S. Control of the shape and size of iron oxide $\left(\alpha-\mathrm{Fe}_{2} \mathrm{O}_{3}\right)$ nanoparticles synthesized through the chemical precipitation method. Results Phys. 2017, 7, 3007-3015. [CrossRef]

34. Tadic, M.; Panjan, M.; Damnjanovic, V.; Milosevic, I. Magnetic properties of hematite $\left(\alpha-\mathrm{Fe}_{2} \mathrm{O}_{3}\right)$ nanoparticles prepared by hydrothermal synthesis method. Appl. Surf. Sci. 2014, 320, 183-187. [CrossRef]

35. Kefeni, K.K.; Msagati, T.A.; Nkambule, T.T.; Mamba, B.B. Synthesis and application of hematite nanoparticles for acid mine drainage treatment. J. Environ. Chem. Eng. 2018, 6, 1865-1874. [CrossRef]

36. Asoufi, H.M.; Al-Antary, T.M.; Awwad, A.M. Green route for synthesis hematite $\left(\alpha-\mathrm{Fe}_{2} \mathrm{O}_{3}\right)$ nanoparticles: Toxicity effect on the green peach aphid, Myzus persicae (Sulzer). Environ. Nanotechnol. Monit. Manag. 2018, 9, 107-111. [CrossRef]

37. Narayanan, K.B.; Han, S.S. One-pot green synthesis of hematite $\left(\alpha-\mathrm{Fe}_{2} \mathrm{O}_{3}\right)$ nanoparticles by ultrasonic irradiation and their in vitro cytotoxicity on human keratinocytes CRL-2310. J. Cluster Sci. 2016, 27, 1763-1775. [CrossRef]

38. Taghavi, F.S.; Ramazani, A.; Golfar, Z.; Woo, J.S. Green synthesis of $\alpha-\mathrm{Fe}_{2} \mathrm{O}_{3}$ (hematite) nanoparticles using tragacanth Gel. J. Appl. Chem. Res. 2017, 11, 19-27.

39. Ali, H.R.; Nassar, H.N.; El-Gendy, N.S. Green synthesis of $\alpha-\mathrm{Fe}_{2} \mathrm{O}_{3}$ using Citrus reticulum peels extract and water decontamination from different organic pollutants. Energ. Source Part A 2017, 39, 1425-1434. [CrossRef]

40. Ahmmad, B.; Leonard, K.; Islam, M.S.; Kurawaki, J.; Muruganandham, M.; Ohkubo, T.; Kuroda, Y. Green synthesis of mesoporous hematite $\left(\alpha-\mathrm{Fe}_{2} \mathrm{O}_{3}\right)$ nanoparticles and their photocatalytic activity. Adv. Powder Technol. 2013, 24, 160-167. [CrossRef]

41. Rufus, A.; Sreeju, N.; Philip, D. Synthesis of biogenic hematite $\left(\alpha-\mathrm{Fe}_{2} \mathrm{O}_{3}\right)$ nanoparticles for antibacterial and nanofluid applications. RSC Adv. 2016, 6, 94206-94217. [CrossRef]

42. Supattarasakda, K.; Petcharoen, K.; Permpool, T.; Sirivat, A.; Lerdwijitjarud, W.J.P.t. Control of hematite nanoparticle size and shape by the chemical precipitation method. Powder Technol. 2013, 249, 353-359. [CrossRef]

43. Anthony, J.W.; Bideaux, R.A.; Bladh, K.W.; Nichols, M.C. Handbook of Mineralogy; Mineralogical Society of America: Chantilly, VA, USA, 2004.

44. Basavegowda, N.; Mishra, K.; Lee, Y.R. Synthesis, characterization, and catalytic applications of hematite $\left(\alpha-\mathrm{Fe}_{2} \mathrm{O}_{3}\right)$ nanoparticles as reusable nanocatalyst. Adv. Nat. Sci. 2017, 8, 025017. [CrossRef]

45. Nazeer, A.A.; Udhayakumar, S.; Mani, S.; Dhanapal, M.; Vijaykumar, S.D. Surface modification of $\mathrm{Fe}_{2} \mathrm{O}_{3}$ and $\mathrm{MgO}$ nanoparticles with agrowastes for the treatment of chlorosis in Glycine max. Nano Converg. 2018, 5, 23. [CrossRef]

46. Danno, T.; Nakatsuka, D.; Kusano, Y.; Asaoka, H.; Nakanishi, M.; Fujii, T.; Ikeda, Y.; Takada, J. Crystal structure of $\beta-\mathrm{Fe}_{2} \mathrm{O}_{3}$ and topotactic phase transformation to $\alpha-\mathrm{Fe}_{2} \mathrm{O}_{3}$. Cryst. Growth Des. 2013, 13, 770-774. [CrossRef]

47. Zhang, N.; Guo, Y.; Wang, X.; Zhang, S.; Li, Z.; Zou, Z. Beta-Fe $\mathrm{O}_{3}$ nanoparticle-assembled film for photoelectrochemical water splitting. Dalton Trans. 2017, 46, 10673-10677. [CrossRef]

48. Kumar, A.; Singhal, A. Synthesis of colloidal $\beta-\mathrm{Fe}_{2} \mathrm{O}_{3}$ nanostructures-Influence of addition of $\mathrm{Co}^{2+}$ on their morphology and magnetic behavior. Nanotechnology 2007, 18, 475703. [CrossRef]

49. Nurdin, I.; Johan, M.; Yaacob, I.; Ang, B.; Andriyana, A. Synthesis, characterisation and stability of superparamagnetic maghemite nanoparticle suspension. Mater. Res. Innov. 2014, 18, 200-203. [CrossRef]

50. Aliahmad, M.; Moghaddam, N.N. Synthesis of maghemite $\left(\gamma-\mathrm{Fe}_{2} \mathrm{O}_{3}\right)$ nanoparticles by thermal-decomposition of magnetite $\left(\mathrm{Fe}_{3} \mathrm{O}_{4}\right)$ nanoparticles. Mater. Sci.-Poland 2013, 31, 264-268. [CrossRef] 
51. Múzquiz-Ramos, E.; Guerrero-Chávez, V.; Macías-Martínez, B.; López-Badillo, C.; García-Cerda, L. Synthesis and characterization of maghemite nanoparticles for hyperthermia applications. Ceram. Int. 2015, 41, 397-402. [CrossRef]

52. Guivar, J.A.R.; Sadrollahi, E.; Menzel, D.; Fernandes, E.G.R.; López, E.O.; Torres, M.M.; Arsuaga, J.M.; Arencibia, A.; Litterst, F.J. Magnetic, structural and surface properties of functionalized maghemite nanoparticles for copper and lead adsorption. RSC Adv. 2017, 7, 28763-28779. [CrossRef]

53. Frison, R.; Cernuto, G.; Cervellino, A.; Zaharko, O.; Colonna, G.M.; Guagliardi, A.; Masciocchi, N. Magnetite-maghemite nanoparticles in the $5-15 \mathrm{~nm}$ range: Correlating the core-shell composition and the surface structure to the magnetic properties. a total scattering study. Chem. Mater. 2013, 25, 4820-4827. [CrossRef]

54. Kera, N.H.; Bhaumik, M.; Pillay, K.; Ray, S.S.; Maity, A. Selective removal of toxic Cr(VI) from aqueous solution by adsorption combined with reduction at a magnetic nanocomposite surface. J. Colloid Interface Sci. 2017, 503, 214-228. [CrossRef]

55. Prado, Y.; Daffé, N.; Michel, A.; Georgelin, T.; Yaacoub, N.; Greneche, J.-M.; Choueikani, F.; Otero, E.; Ohresser, P.; Arrio, M.-A. Enhancing the magnetic anisotropy of maghemite nanoparticles via the surface coordination of molecular complexes. Nat. Commun. 2015, 6, 10139. [CrossRef]

56. Mazarío, E.; Helal, A.S.; Stemper, J.; Mayoral, A.; Decorse, P.; Chevillot-Biraud, A.; Novak, S.; Perruchot, C.; Lion, C.; Losno, R. Maghemite nanoparticles bearing di(amidoxime) groups for the extraction of uranium from wastewaters. AIP Adv. 2017, 7, 056702. [CrossRef]

57. Palmqvist, N.M.; Seisenbaeva, G.A.; Svedlindh, P.; Kessler, V.G. Maghemite nanoparticles acts as nanozymes, improving growth and abiotic stress tolerance in Brassica napus. Nanoscale Res. Lett. 2017, 12, 631. [CrossRef] [PubMed]

58. Tavakkoli, M.; Kallio, T.; Reynaud, O.; Nasibulin, A.G.; Sainio, J.; Jiang, H.; Kauppinen, E.I.; Laasonen, K. Maghemite nanoparticles decorated on carbon nanotubes as efficient electrocatalysts for the oxygen evolution reaction. J. Mater. Chem. A 2016, 4, 5216-5222. [CrossRef]

59. Hu, J.; Chen, G.; Lo, I.M. Removal and recovery of $\mathrm{Cr}(\mathrm{VI})$ from wastewater by maghemite nanoparticles. Water Res. 2005, 39, 4528-4536. [CrossRef]

60. Jiang, W.; Pelaez, M.; Dionysiou, D.D.; Entezari, M.H.; Tsoutsou, D.; O'Shea, K. Chromium(VI) removal by maghemite nanoparticles. Chem. Eng. J. 2013, 222, 527-533. [CrossRef]

61. Avram, A.; Radoi, A.; Schiopu, V.; Avram, M.; Gavrila, H. Synthesis and characterization of $\gamma-\mathrm{Fe}_{2} \mathrm{O}_{3}$ nanoparticles for applications in magnetic hyperthermia. Synthesis 2011, 10, 1.

62. Mercante, L.; Melo, W.; Granada, M.; Troiani, H.; Macedo, W.; Ardison, J.; Vaz, M.; Novak, M. Magnetic properties of nanoscale crystalline maghemite obtained by a new synthetic route. J. Magn. Magn. Mater. 2012, 324, 3029-3033. [CrossRef]

63. Kuchma, E.A.; Zolotukhin, P.V.; Belanova, A.A.; Soldatov, M.A.; Lastovina, T.A.; Kubrin, S.P.; Nikolsky, A.V.; Mirmikova, L.I.; Soldatov, A.V. Low toxic maghemite nanoparticles for theranostic applications. Int. J. Nanomed. 2017, 12, 6365-6371. [CrossRef]

64. Kumar, N.; Kulkarni, K.; Behera, L.; Verma, V. Preparation and characterization of maghemite nanoparticles from mild steel for magnetically guided drug therapy. J. Mater. Sci. Mater. Med. 2017, 28, 116. [CrossRef]

65. Blanc-Beguin, F.; Nabily, S.; Gieraltowski, J.; Turzo, A.; Querellou, S.; Salaun, P. Cytotoxicity and GMI bio-sensor detection of maghemite nanoparticles internalized into cells. J. Magn. Magn. Mater. 2009, 321, 192-197. [CrossRef]

66. Perlstein, B.; Lublin-Tennenbaum, T.; Marom, I.; Margel, S. Synthesis and characterization of functionalized magnetic maghemite nanoparticles with fluorescent probe capabilities for biological applications. J. Biomed. Mater. Res. B Appl. Biomater. 2010, 92, 353-360. [CrossRef] [PubMed]

67. Hai, J.; Piraux, H.; Mazario, E.; Volatron, J.; Ha-Duong, N.; Decorse, P.; Lomas, J.; Verbeke, P.; Ammar, S.; Wilhelm, C. Maghemite nanoparticles coated with human serum albumin: Combining targeting by the iron-acquisition pathway and potential in photothermal therapies. J. Mater. Chem. B 2017, 5, 3154-3162. [CrossRef] [PubMed]

68. González, B.; Ruiz-Hernández, E.; Feito, M.J.; de Laorden, C.L.; Arcos, D.; Ramírez-Santillán, C.; Matesanz, C.; Portolés, M.T.; Vallet-Regí, M. Covalently bonded dendrimer-maghemite nanosystems: Nonviral vectors for in vitro gene magnetofection. J. Mater. Chem. 2011, 21, 4598-4604. [CrossRef] 
69. Hai, J.; Piraux, H.; Mazario, E.; Volatron, J.; Ha-Duong, N.; Decorse, P.; Espinosa, A.; Whilem, C.; Verbeke, P.; Gazeau, F. Multifunctionality of maghemite nanoparticles functionalized by HSA for drug delivery. In Proceedings of the 2017 IEEE International Magnetics Conference (INTERMAG), Dublin, Ireland, 24-28 April 2017; pp. 1-2.

70. Štarha, P.; Stavárek, M.; Tuček, J.; Trávníček, Z. 4-Aminobenzoic acid-coated maghemite nanoparticles as potential anticancer drug magnetic carriers: A case study on highly cytotoxic cisplatin-like complexes involving 7-azaindoles. Molecules 2014, 19, 1622-1634. [CrossRef] [PubMed]

71. Thünemann, A.F.; Schütt, D.; Kaufner, L.; Pison, U.; Möhwald, H. Maghemite nanoparticles protectively coated with poly (ethylene imine) and poly (ethylene oxide)-b lock-poly (glutamic acid). Langmuir 2006, 22, 2351-2357. [CrossRef]

72. Liu, J.; Detrembleur, C.; Debuigne, A.; De Pauw-Gillet, M.-C.; Mornet, S.; Vander Elst, L.; Laurent, S.; Duguet, E.; Jérôme, C. Glucose-, pH-and thermo-responsive nanogels crosslinked by functional superparamagnetic maghemite nanoparticles as innovative drug delivery systems. J. Mater. Chem. B 2014, 2, 1009-1023. [CrossRef]

73. Blyakhman, F.A.; Safronov, A.P.; Zubarev, A.Y.; Shklyar, T.F.; Makeyev, O.G.; Makarova, E.B.; Melekhin, V.V.; Larrañaga, A.; Kurlyandskaya, G.V. Polyacrylamide ferrogels with embedded maghemite nanoparticles for biomedical engineering. Results Phys. 2017, 7, 3624-3633. [CrossRef]

74. Kim, J.-J.; Singh, R.K.; Seo, S.-J.; Kim, T.-H.; Kim, J.-H.; Lee, E.-J.; Kim, H.-W. Magnetic scaffolds of polycaprolactone with functionalized magnetite nanoparticles: Physicochemical, mechanical, and biological properties effective for bone regeneration. RSC Adv. 2014, 4, 17325-17336. [CrossRef]

75. Ngadiman, N.H.A.; Idris, A.; Irfan, M.; Kurniawan, D.; Yusof, N.M.; Nasiri, R. $\gamma-\mathrm{Fe}_{2} \mathrm{O}_{3}$ nanoparticles filled polyvinyl alcohol as potential biomaterial for tissue engineering scaffold. J. Mech. Behav. Biomed. Mater. 2015, 49, 90-104. [CrossRef]

76. Fallahiarezoudar, E.; Ahmadipourroudposht, M.; Idris, A.; Yusof, N.M. Optimization and development of Maghemite $\left(\gamma-\mathrm{Fe}_{2} \mathrm{O}_{3}\right)$ filled poly-L-lactic acid (PLLA)/thermoplastic polyurethane (TPU) electrospun nanofibers using Taguchi orthogonal array for tissue engineering heart valve. Mater. Sci. Eng. C 2017, 76, 616-627. [CrossRef]

77. Chirita, M.; Grozescu, I.; Taubert, L.; Radulescu, H.; Princz, E. $\mathrm{Fe}_{2} \mathrm{O}_{3}$-nanoparticles, physical properties and their photochemical and photoelectrochemical applications. Chem. Bull. 2009, 54, 1-8.

78. Tucek, J.; Zboril, R.; Namai, A.; Ohkoshi, S.-i. $\varepsilon-\mathrm{Fe}_{2} \mathrm{O}_{3}$ : An advanced nanomaterial exhibiting giant coercive field, millimeter-wave ferromagnetic resonance, and magnetoelectric coupling. Chem. Mater. 2010, 22, 6483-6505. [CrossRef]

79. López-Sánchez, J.; Muñoz-Noval, A.; Serrano, A.; Abuín, M.; de la Figuera, J.; Marco, J.; Pérez, L.; Carmona, N.; de la Fuente, O.R. Growth, structure and magnetism of $\varepsilon-\mathrm{Fe}_{2} \mathrm{O}_{3}$ in nanoparticle form. RSC Adv. 2016, 6, 46380-46387. [CrossRef]

80. Ohkoshi, S.-i.; Namai, A.; Yamaoka, T.; Yoshikiyo, M.; Imoto, K.; Nasu, T.; Anan, S.; Umeta, Y.; Nakagawa, K.; Tokoro, H. Mesoscopic bar magnet based on $\varepsilon-\mathrm{Fe}_{2} \mathrm{O}_{3}$ hard ferrite. Sci. Rep. 2016, 6, 27212. [CrossRef]

81. Tuček, J.; Machala, L.; Ono, S.; Namai, A.; Yoshikiyo, M.; Imoto, K.; Tokoro, H.; Ohkoshi, S.-i.; Zbořil, R. Zeta- $\mathrm{Fe}_{2} \mathrm{O}_{3}-\mathrm{A}$ new stable polymorph in iron(III) oxide family. Sci. Rep. 2015, 5, 15091. [CrossRef]

82. Lynch, S.; Batty, L.; Byrne, P. Environmental risk of metal mining contaminated river bank sediment at redox-transitional zones. Minerals 2014, 4, 52-73. [CrossRef]

83. Mohapatra, M.; Anand, S. Synthesis and applications of nano-structured iron oxides/hydroxides-A review. Int. J. Eng. Sci. Technol. 2010, 2, 127-146. [CrossRef]

84. Eusterhues, K.; Wagner, F.E.; Häusler, W.; Hanzlik, M.; Knicker, H.; Totsche, K.U.; KÖgel-Knabner, I.; Schwertmann, U. Characterization of ferrihydrite-soil organic matter coprecipitates by X-ray diffraction and Mossbauer spectroscopy. Environ. Sci. Technol. 2008, 42, 7891-7897. [CrossRef]

85. Poulson, R.L.; Johnson, C.M.; Beard, B.L. Iron isotope exchange kinetics at the nanoparticulate ferrihydrite surface. Am. Mineral. 2005, 90, 758-763. [CrossRef]

86. Chasteen, N.D.; Harrison, P.M. Mineralization in ferritin: An efficient means of iron storage. J. Struct. Biol. 1999, 126, 182-194. [CrossRef]

87. Liu, G.; Debnath, S.; Paul, K.W.; Han, W.; Hausner, D.B.; Hosein, H.-A.; Michel, F.M.; Parise, J.B.; Sparks, D.L.; Strongin, D.R. Characterization and surface reactivity of ferrihydrite nanoparticles assembled in ferritin. Langmuir 2006, 22, 9313-9321. [CrossRef] [PubMed] 
88. Baldi, F.; Marchetto, D.; Battistel, D.; Daniele, S.; Faleri, C.; De Castro, C.; Lanzetta, R. Iron-binding characterization and polysaccharide production by Klebsiella oxytoca strain isolated from mine acid drainage. J. Appl. Microbiol. 2009, 107, 1241-1250. [CrossRef] [PubMed]

89. Baldi, F.; Marchetto, D.; Paganelli, S.; Piccolo, O. Bio-generated metal binding polysaccharides as catalysts for synthetic applications and organic pollutant transformations. N. Biotechnol. 2011, 29, 74-78. [CrossRef] [PubMed]

90. Baldi, F.; Minacci, A.; Pepi, M.; Scozzafava, A. Gel sequestration of heavy metals by Klebsiella oxytoca isolated from iron mat. FEMS Microbiol. Ecol. 2001, 36, 169-174. [CrossRef] [PubMed]

91. Kianpour, S.; Ebrahiminezhad, A.; Mohkam, M.; Tamaddon, A.M.; Dehshahri, A.; Heidari, R.; Ghasemi, Y. Physicochemical and biological characteristics of the nanostructured polysaccharide-iron hydrogel produced by microorganism Klebsiella oxytoca. J. Basic Microbiol. 2016, 2016, 132-140. [CrossRef]

92. Kianpour, S.; Ebrahiminezhad, A.; Deyhimi, M.; Negahdaripour, M.; Raee, M.j.; Mohkam, M.; Rezaee, H.; Irajie, C.; Berenjian, A.; Ghasemi, Y. Structural characterization of polysaccharide-coated iron oxide nanoparticles produced by Staphylococcus warneri, isolated from a thermal spring. J. Basic Microbiol. 2019, 2019, 1-10. [CrossRef]

93. Kianpour, S.; Ebrahiminezhad, A.; Negahdaripour, M.; Mohkam, M.; Mohammadi, F.; Niknezhad, S.; Ghasemi, Y. Characterization of biogenic Fe (III)-binding exopolysaccharide nanoparticles produced by Ralstonia sp. SK03. Biotechnol. Prog. 2018, 34, 1167-1176. [CrossRef]

94. Ebrahiminezhad, A.; Zare, M.; Kiyanpour, S.; Berenjian, A.; Niknezhad, S.V.; Ghasemi, Y. Biosynthesis of xanthan gum coated iron nanoparticles by using Xanthomonas campestris. IET Nanobiotechnol. 2017, 151, 684-691. [CrossRef]

95. Stolyar, S.; Yaroslavtsev, R.; Bayukov, O.; Balaev, D.; Krasikov, A.; Iskhakov, R.; Vorotynov, A.; Ladygina, V.; Purtov, K.; Volochaev, M. Preparation, structure and magnetic properties of synthetic ferrihydrite nanoparticles. J. Phys. Conf. Ser. 2018, 994, 012003. [CrossRef]

96. Villacís-García, M.; Ugalde-Arzate, M.; Vaca-Escobar, K.; Villalobos, M.; Martínez-Villegas, N. Laboratory synthesis of goethite and ferrihydrite of controlled particle sizes. Bol. Soc. Geol. Mex. 2015, 67, 433-446. [CrossRef]

97. Sokolov, I.; Cherkasov, V.; Vasilyeva, A.; Bragina, V.; Nikitin, M. Paramagnetic colloidal ferrihydrite nanoparticles for MRI contrasting. Colloids Surf. Physicochem. Eng. Aspects 2018, 539, 46-52. [CrossRef]

98. Balaev, D.; Krasikov, A.; Dubrovskiy, A.; Popkov, S.; Stolyar, S.; Bayukov, O.; Iskhakov, R.; Ladygina, V.; Yaroslavtsev, R. Magnetic properties of heat treated bacterial ferrihydrite nanoparticles. J. Magn. Magn. Mater. 2016, 410, 171-180. [CrossRef]

99. Rout, K.; Mohapatra, M.; Anand, S. 2-Line ferrihydrite: Synthesis, characterization and its adsorption behaviour for removal of $\mathrm{Pb}(\mathrm{II}), \mathrm{Cd}(\mathrm{II}), \mathrm{Cu}(\mathrm{II})$ and $\mathrm{Zn}$ (II) from aqueous solutions. Dalton Trans. 2012, 41, 3302-3312. [CrossRef] [PubMed]

100. Antelo, J.; Arce, F.; Fiol, S. Arsenate and phosphate adsorption on ferrihydrite nanoparticles. synergetic interaction with calcium ions. Chem. Geol. 2015, 410, 53-62. [CrossRef]

101. Tosco, T.; Bosch, J.; Meckenstock, R.U.; Sethi, R. Transport of ferrihydrite nanoparticles in saturated porous media: Role of ionic strength and flow rate. Environ. Sci. Technol. 2012, 46, 4008-4015. [CrossRef]

102. Xiang, A.; Yan, W.; Koel, B.E.; Jaffé, P.R. Poly(acrylic acid) coating induced 2-line ferrihydrite nanoparticle transport in saturated porous media. J. Nanopart. Res. 2013, 15, 1705. [CrossRef]

103. Pariona, N.; Martinez, A.I.; Hdz-García, H.; Cruz, L.A.; Hernandez-Valdes, A. Effects of hematite and ferrihydrite nanoparticles on germination and growth of maize seedlings. Saudi J. Biol. Sci. 2017, 24, 1547-1554. [CrossRef]

104. Majidi, S.; Zeinali Sehrig, F.; Farkhani, S.M.; Soleymani Goloujeh, M.; Akbarzadeh, A. Current methods for synthesis of magnetic nanoparticles. Artif. Cells Nanomed. Biotechnol. 2016, 44, 722-734. [CrossRef]

105. Döpke, C.; Grothe, T.; Steblinski, P.; Klöcker, M.; Sabantina, L.; Kosmalska, D.; Blachowicz, T.; Ehrmann, A. Magnetic nanofiber mats for data storage and transfer. Nanomaterials 2019, 9, 92. [CrossRef] [PubMed]

106. Domingos, D.G.; Henriques, R.O.; Xavier, J.A.; Junior, N.L.; da Costa, R.H.R. Increasing activated sludge aggregation by magnetite nanoparticles addition. Water Sci. Technol. 2019, 79, 993-999. [CrossRef]

107. Alfaro, I.; Molina, L.; González, P.; Gaete, J.; Valenzuela, F.; Marco, J.F.; Sáez, C.; Basualto, C. Silica-coated magnetite nanoparticles functionalized with betaine and their use as an adsorbent for Mo(VI) and $\operatorname{Re}(\mathrm{VII})$ species from acidic aqueous solutions. J. Ind. Eng. Chem. 2019, 78, 271-283. [CrossRef] 
108. Molina, L.; Gaete, J.; Alfaro, I.; Ide, V.; Valenzuela, F.; Parada, J.; Basualto, C. Synthesis and characterization of magnetite nanoparticles functionalized with organophosphorus compounds and its application as an adsorbent for $\mathrm{La}(\mathrm{III}), \mathrm{Nd}(\mathrm{III})$ and $\mathrm{Pr}(\mathrm{III})$ ions from aqueous solutions. J. Mol. Liq. 2019, 275, 178-191. [CrossRef]

109. Veisi, H.; Razeghi, S.; Mohammadi, P.; Hemmati, S. Silver nanoparticles decorated on thiol-modified magnetite nanoparticles $\left(\mathrm{Fe}_{3} \mathrm{O}_{4} / \mathrm{SiO}_{2}-\mathrm{Pr}-\mathrm{S}-\mathrm{Ag}\right)$ as a recyclable nanocatalyst for degradation of organic dyes. Mater. Sci. Eng. C 2019, 97, 624-631. [CrossRef] [PubMed]

110. Guo, T.; Lin, M.; Huang, J.; Zhou, C.; Tian, W.; Yu, H.; Jiang, X.; Ye, J.; Shi, Y.; Xiao, Y. The recent advances of magnetic nanoparticles in Medicine. J. Nanomater. 2018, 2018, 7805147. [CrossRef]

111. Thanh, B.T.; Hai, T.H.; Van, P.H.; Minh Tung, L.; Lee, J. Detection of hepatitis B surface antigen by immunoassay using magnetite nanoparticles binding hepatitis B surface antibody. Geosystem Eng. 2019, 22, 206-213. [CrossRef]

112. Gupta, A.K.; Wells, S. Surface-modified superparamagnetic nanoparticles for drug delivery: Preparation, characterization, and cytotoxicity studies. IEEE Trans. NanoBiosci. 2004, 3, 66-73. [CrossRef]

113. Ebrahiminezhad, A.; Davaran, S.; Rasoul-Amini, S.; Barar, J.; Moghadam, M.; Ghasemi, Y. Synthesis, characterization and anti-Listeria monocytogenes effect of amino acid coated magnetite nanoparticles. Curr. Nanosci. 2012, 8, 868-874. [CrossRef]

114. Ebrahiminezhad, A.; Ghasemi, Y.; Rasoul-Amini, S.; Barar, J.; Davaran, S. Impact of amino-acid coating on the synthesis and characteristics of iron-oxide nanoparticles (IONs). Bull. Korean Chem. Soc. 2012, 33, 3957-3962. [CrossRef]

115. Ebrahiminezhad, A.; Ghasemi, Y.; Rasoul-Amini, S.; Barar, J.; Davaran, S. Preparation of novel magnetic fluorescent nanoparticles using amino acids. Colloids Surf. B. 2013, 102, 534-539. [CrossRef]

116. Ebrahiminezhad, A.; Rasoul-Amini, S.; Davaran, S.; Barar, J.; Ghasemi, Y. Impacts of iron oxide nanoparticles on the invasion power of Listeria monocytogenes. Curr. Nanosci. 2014, 10, 382-388. [CrossRef]

117. Ebrahiminezhad, A.; Rasoul-Amini, S.; Kouhpayeh, A.; Davaran, S.; Barar, J.; Ghasemi, Y. Impacts of amine functionalized iron oxide nanoparticles on HepG2 cell line. Curr. Nanosci. 2015, 11, 113-119. [CrossRef]

118. Ebrahiminezhad, A.; Varma, V.; Yang, S.; Berenjian, A. Magnetic immobilization of Bacillus subtilis natto cells for menaquinone-7 fermentation. Appl. Microbiol. Biotechnol. 2016, 100, 173-180. [CrossRef] [PubMed]

119. Ebrahiminezhad, A.; Varma, V.; Yang, S.; Ghasemi, Y.; Berenjian, A. Synthesis and application of amine functionalized iron oxide nanoparticles on menaquinone-7 fermentation: A step towards process intensification. Nanomaterials 2015, 6, 1. [CrossRef] [PubMed]

120. Gholami, A.; Rasoul-Amini, S.; Ebrahiminezhad, A.; Abootalebi, N.; Niroumand, U.; Ebrahimi, N.; Ghasemi, Y. Magnetic properties and antimicrobial effect of amino and lipoamino acid coated iron oxide nanoparticles. Minerva Biotecnol. 2016, 28, 177-186.

121. Gholami, A.; Rasoul-amini, S.; Ebrahiminezhad, A.; Seradj, S.H.; Ghasemi, Y. Lipoamino acid coated superparamagnetic iron oxide nanoparticles concentration and time dependently enhanced growth of human hepatocarcinoma cell line (Hep-G2). J. Nanomater. 2015, 2015, 451405. [CrossRef]

122. Berry, C.C.; Wells, S.; Charles, S.; Curtis, A.S.G. Dextran and albumin derivatised iron oxide nanoparticles: Influence on fibroblasts in vitro. Biomaterials 2003, 24, 4551-4557. [CrossRef]

123. Raee, M.J.; Ebrahiminezhad, A.; Gholami, A.; Ghoshoon, M.B.; Ghasemi, Y. Magnetic immobilization of recombinant E. coli producing extracellular asparaginase: An effective way to intensify downstream process. Sep. Sci. Technol. 2018, 53, 1397-1404. [CrossRef]

124. Ranmadugala, D.; Ebrahiminezhad, A.; Manley-Harris, M.; Ghasemi, Y.; Berenjian, A. Iron oxide nanoparticles in modern microbiology and biotechnology. Crit. Rev. Microbiol. 2017, 43, 493-507. [CrossRef]

125. Ranmadugala, D.; Ebrahiminezhad, A.; Manley-Harris, M.; Ghasemi, Y.; Berenjian, A. Magnetic immobilization of bacteria using iron oxide nanoparticles. Biotechnol. Lett. 2017, 40, 237-248. [CrossRef]

126. Seifan, M.; Sarmah, A.K.; Samani, A.K.; Ebrahiminezhad, A.; Ghasemi, Y.; Berenjian, A. Mechanical properties of bio self-healing concrete containing immobilized bacteria with iron oxide nanoparticles. Appl. Microbiol. Biotechnol. 2018, 102, 4489-4498. [CrossRef]

127. Seifan, M.; Ebrahiminezhad, A.; Ghasemi, Y.; Berenjian, A. Microbial calcium carbonate precipitation with high affinity to fill the concrete pore space: Nanobiotechnological approach. Bioprocess Biosyst. Eng. 2019, 42, 37-46. [CrossRef] [PubMed] 
128. Seifan, M.; Ebrahiminezhad, A.; Ghasemi, Y.; Samani, A.K.; Berenjian, A. Amine-modified magnetic iron oxide nanoparticle as a promising carrier for application in bio self-healing concrete. Appl. Microbiol. Biotechnol. 2017, 102, 175-184. [CrossRef] [PubMed]

129. Seifan, M.; Ebrahiminezhad, A.; Ghasemi, Y.; Samani, A.K.; Berenjian, A. The role of magnetic iron oxide nanoparticles in the bacterially induced calcium carbonate precipitation. Appl. Microbiol. Biotechnol. 2018, 102, 3595-3606. [CrossRef] [PubMed]

130. Seifan, M.; Sarmah, A.K.; Ebrahiminezhad, A.; Ghasemi, Y.; Samani, A.K.; Berenjian, A. Bio-reinforced self-healing concrete using magnetic iron oxide nanoparticles. Appl. Microbiol. Biotechnol. 2018, 102, 2167-2178. [CrossRef] [PubMed]

131. Ernst, C.; Bartel, A.; Elferink, J.W.; Huhn, J.; Eschbach, E.; Schönfeld, K.; Feßler, A.T.; Oberheitmann, B.; Schwarz, S. Improved DNA extraction and purification with magnetic nanoparticles for the detection of methicillin-resistant Staphylococcus aureus. Vet. Microbiol. 2019, 230, 45-48. [CrossRef]

132. Haghighi, A.H.; Faghih, Z.; Khorasani, M.T.; Farjadian, F. Antibody conjugated onto surface modified magnetic nanoparticles for separation of HER2+ breast cancer cells. J. Magn. Magn. Mater. 2019, 490, 165479. [CrossRef]

133. Orhan, H.; Evli, S.; Dabanca, M.B.; Başbülbül, G.; Uygun, M.; Uygun, D.A. Bacteria killer enzyme attached magnetic nanoparticles. Mater. Sci. Eng. C 2019, 94, 558-564. [CrossRef]

134. Berovic, M.; Berlot, M.; Kralj, S.; Makovec, D. A new method for the rapid separation of magnetized yeast in sparkling wine. Biochem. Eng. J. 2014, 88, 77-84. [CrossRef]

135. Taghizadeh, S.-M.; Ebrahiminezhad, A.; Ghoshoon, M.B.; Dehshahri, A.; Berenjian, A.; Ghasemi, Y. Magnetic immobilization of Pichia pastoris cells for the production of recombinant human serum albumin. Nanomaterials 2020, 10, 111. [CrossRef]

136. Taghizadeh, S.M.; Berenjian, A.; Chew, K.W.; Show, P.L.; Mohd Zaid, H.F.; Ramezani, H.; Ghasemi, Y.; Raee, M.J.; Ebrahiminezhad, A. Impact of magnetic immobilization on the cell physiology of green unicellular algae Chlorella vulgaris. Bioengineered 2020, 11, 141-153. [CrossRef]

137. Ansari, F.; Grigoriev, P.; Libor, S.; Tothill, I.E.; Ramsden, J.J. DBT degradation enhancement by decorating Rhodococcus erythropolis IGST8 with magnetic $\mathrm{Fe}_{3} \mathrm{O}_{4}$ nanoparticles. Biotechnol. Bioeng. 2009, 102, 1505-1512. [CrossRef] [PubMed]

138. Ranmadugala, D.; Ebrahiminezhad, A.; Manley-Harris, M.; Ghasemi, Y.; Berenjian, A. Impact of 3-aminopropyltriethoxysilane-coated iron oxide nanoparticles on menaquinone-7 production using $B$. subtilis. Nanomaterials 2017, 7, 350. [CrossRef] [PubMed]

139. Ranmadugala, D.; Ebrahiminezhad, A.; Manley-Harris, M.; Ghasemi, Y.; Berenjian, A. The effect of iron oxide nanoparticles on Bacillus subtilis biofilm, growth and viability. Process Biochem. 2017, 62, 231-240. [CrossRef]

140. Ranmadugala, D.; Ebrahiminezhad, A.; Manley-Harris, M.; Ghasemi, Y.; Berenjian, A. Reduced biofilm formation in Menaquinone-7 production process by optimizing the composition of the cultivation medium. Trends Pharma. Sci. 2017, 3, 245-254.

141. Taghizadeh, S.-M.; Jafari, S.; Ahmad-Kiadaliri, T.; Mobasher, M.A.; Lal, N.; Raee, M.J.; Berenjian, A.; Ghasemi, Y.; Ebrahiminezhad, A. Magnetic immobilisation as a promising approach against bacteriophage infection. Mater. Res. Express. 2019, 6. [CrossRef]

142. Dieudonné, A.; Pignol, D.; Prévéral, S. Magnetosomes: Biogenic iron nanoparticles produced by environmental bacteria. Appl. Microbiol. Biotechnol. 2019, 103, 3637-3649. [CrossRef]

143. Yamazaki, T.; Suzuki, Y.; Kouduka, M.; Kawamura, N. Dependence of bacterial magnetosome morphology on chemical conditions in deep-sea sediments. Earth. Planet. Sci. Lett. 2019, 513, 135-143. [CrossRef]

144. Gorobets, S.; Gorobets, O.; Bulaievska, M.; Sharay, I. Detection of biogenic magnetic nanoparticles in ethmoid bones of migratory and non-migratory fishes. SN Appl. Sci. 2019, 1, 63. [CrossRef]

145. Gorobets, S.; Gorobets, O.; Magerman, A.; Gorobets, Y.; Sharay, I. Biogenic magnetic nanoparticles in plants. arXiv 2019, arXiv:1901.07212.

146. Murros, K.E.; Salminen, J.; Wasiljeff, J.; Macías-Sánchez, E.; Soinne, L.S.; Faivre, D.; Valtonen, J.; Pohja, M.; Saari, P.; Pesonen, L. Magnetic nanoparticles in human cervical skin. Front. Med. 2019, 6, 123. [CrossRef]

147. Van de Walle, A.; Sangnier, A.P.; Abou-Hassan, A.; Curcio, A.; Hémadi, M.; Menguy, N.; Lalatonne, Y.; Luciani, N.; Wilhelm, C. Biosynthesis of magnetic nanoparticles from nano-degradation products revealed in human stem cells. Proc. Natl. Acad. Sci. USA 2019, 116, 4044-4053. [CrossRef] [PubMed] 
148. Brok, E.; Frandsen, C.; Madsen, D.E.; Jacobsen, H.; Birk, J.; Lefmann, K.; Bendix, J.; Pedersen, K.; Boothroyd, C.; Berhe, A. Magnetic properties of ultra-small goethite nanoparticles. J. Phys. D Appl. Phys. 2014, 47, 365003. [CrossRef]

149. van der Zee, C.; Roberts, D.R.; Rancourt, D.G.; Slomp, C.P. Nanogoethite is the dominant reactive oxyhydroxide phase in lake and marine sediments. Geology 2003, 31, 993-996. [CrossRef]

150. Ghanbariasad, A.; Taghizadeh, S.-M.; Show, P.L.; Nomanbhay, S.; Berenjian, A.; Ghasemi, Y.; Ebrahiminezhad, A. Controlled synthesis of iron oxyhydroxide (FeOOH) nanoparticles using secretory compounds from Chlorella vulgaris microalgae. Bioengineered 2019, 10, 390-396. [CrossRef] [PubMed]

151. Nguyen, V.; Kynicky, J.; Ambrozova, P.; Adam, V. Microwave-Assisted Synthesis of Goethite Nanoparticles Used for Removal of Cr (VI) from Aqueous Solution. Materials 2017, 10, 783. [CrossRef] [PubMed]

152. Ghosh, M.K.; Poinern, G.E.J.; Issa, T.B.; Singh, P. Arsenic adsorption on goethite nanoparticles produced through hydrazine sulfate assisted synthesis method. Korean J. Chem. Eng. 2012, 29, 95-102. [CrossRef]

153. Kar, S.; Equeenuddin, S.M. Adsorption of hexavalent chromium using natural goethite: Isotherm, thermodynamic and kinetic study. J. Geol. Soc. India 2019, 93, 285-292. [CrossRef]

154. Adegoke, H.; Adekola, F.; Ashola, M. Adsorptive removal of hexavalent chromium using synthetic goethite nanoparticles. Niger. J. Chem. Res. 2018, 23, 20-38.

155. Tiraferri, A.; Hernandez, L.A.S.; Bianco, C.; Tosco, T.; Sethi, R. Colloidal behavior of goethite nanoparticles modified with humic acid and implications for aquifer reclamation. J. Nanopart. Res. 2017, 19, 107. [CrossRef]

156. Kalishyn, Y.; Bychko, I.; Polunkin, E.; Kameneva, T.; Strizhak, P. Enhancement in the oxidative stability of commercial gasoline fuel by the goethite nanoparticles. ChemRxiv. Preprint 2018. [CrossRef]

157. Zhao, J.; Lin, W.; Chang, Q.; Li, W.; Lai, Y. Adsorptive characteristics of akaganeite and its environmental applications: A review. Environ. Technol. Rev. 2012, 1, 114-126. [CrossRef]

158. Kim, J.; Grey, C.P. ${ }^{2} \mathrm{H}$ and ${ }^{7} \mathrm{Li}$ solid-state MAS NMR study of local environments and lithium adsorption on the iron(III) oxyhydroxide, akaganeite ( $\beta-\mathrm{FeOOH})$. Chem. Mater. 2010, 22, 5453-5462. [CrossRef]

159. Mohapatra, J.; Mitra, A.; Tyagi, H.; Bahadur, D.; Aslam, M. Iron oxide nanorods as high-performance magnetic resonance imaging contrast agents. Nanoscale 2015, 7, 9174-9184. [CrossRef] [PubMed]

160. Kasparis, G.; Erdocio, A.S.; Tuffnell, J.M.; Thanh, N.T.K. Synthesis of size-tuneable $\beta$-FeOOH nanoellipsoids and a study of their morphological and compositional changes by reduction. CrystEngComm 2019, 21, 1293-1301. [CrossRef]

161. Yuan, Z.-Y.; Su, B.-L. Surfactant-assisted nanoparticle assembly of mesoporous $\beta$-FeOOH (akaganeite). Chem. Phys. Lett. 2003, 381, 710-714. [CrossRef]

162. Faria, M.C.; Rosemberg, R.S.; Bomfeti, C.A.; Monteiro, D.S.; Barbosa, F.; Oliveira, L.C.; Rodriguez, M.; Pereira, M.C.; Rodrigues, J.L. Arsenic removal from contaminated water by ultrafine $\delta$-FeOOH adsorbents. Chem. Eng. J. 2014, 237, 47-54. [CrossRef]

163. Zhang, Y.-X.; Jia, Y. A facile solution approach for the synthesis of akaganéite ( $\beta$-FeOOH) nanorods and their ion-exchange mechanism toward As(V) ions. Appl. Surf. Sci. 2014, 290, 102-106. [CrossRef]

164. Legg, B.A. The Formation and Aggregation of Iron Oxyhydroxide Nanoparticles in the Aqueous Environment. Ph.D. Thesis, UC Berkeley, Berkeley, CA, USA, 2013.

165. Majzlan, J.; Mazeina, L.; Navrotsky, A. Enthalpy of water adsorption and surface enthalpy of lepidocrocite $(\gamma$-FeOOH). Geochim. Cosmochim. Acta 2007, 71, 615-623. [CrossRef]

166. Vindedahl, A.M.; Strehlau, J.H.; Arnold, W.A.; Penn, R.L. Organic matter and iron oxide nanoparticles: Aggregation, interactions, and reactivity. Environ. Sci. Nano 2016, 3, 494-505. [CrossRef]

167. Navarro, G.; Acevedo, R.; Soto, A.; Herane, M. Synthesis and characterization of lepidocrocite and its potential applications in the adsorption of pollutant species. J. Phys. Conf. Ser. 2008, 134, 012023. [CrossRef]

168. Lee, G.; Kim, S.; Choi, B.; Huh, S.; Chang, Y.; Kim, B.; Park, J.; Oh, S. Magnetic properties of needle-like $\alpha$-FeOOH and $\gamma$-FeOOH nanoparticles. J. Korean Phys. Soc. 2004, 45, 1019-1024.

169. Ewing, F. The crystal structure of lepidocrocite. J. Chem. Phys. 1935, 3, 420-424. [CrossRef]

170. Liu, A.; Liu, J.; Pan, B.; Zhang, W.-x. Formation of lepidocrocite ( $\gamma$-FeOOH) from oxidation of nanoscale zero-valent iron (nZVI) in oxygenated water. RSC Adv. 2014, 4, 57377-57382. [CrossRef]

171. Agarwal, A.; Joshi, H.; Kumar, A. Synthesis, characterization and application of nano lepidocrocite and magnetite in the degradation of carbon tetrachloride. S. Afr. J. Chem. 2011, 64, 218-224.

172. Sheydaei, M.; Aber, S. Preparation of nano-lepidocrocite and an investigation of its ability to remove a metal complex dye. Clean 2013, 41, 890-898. [CrossRef] 
173. Alexandratos, V.G.; Behrends, T.; Van Cappellen, P. Fate of adsorbed U(VI) during sulfidization of lepidocrocite and hematite. Environ. Sci. Technol. 2017, 51, 2140-2150. [CrossRef]

174. O'Loughlin, E.J.; Gorski, C.A.; Flynn, T.M.; Scherer, M.M. Electron donor utilization and secondary mineral formation during the bioreduction of lepidocrocite by Shewanella putrefaciens CN32. Minerals 2019, 9, 434. [CrossRef]

175. Koch, C.B.; Oxborrow, C.; Mørup, S.; Madsen, M.; Quinn, A.; Coey, J. Magnetic properties of feroxyhyte ( $\delta$-FeOOH). Phys. Chem. Miner. 1995, 22, 333-341. [CrossRef]

176. Chen, P.; Xu, K.; Li, X.; Guo, Y.; Zhou, D.; Zhao, J.; Wu, X.; Wu, C.; Xie, Y. Ultrathin nanosheets of feroxyhyte: A new two-dimensional material with robust ferromagnetic behavior. Chem. Sci. 2014, 5, 2251-2255. [CrossRef]

177. Chukhrov, F.; Zvyagin, B.; Gorshkov, A.; Yermilova, L.; Korovushkin, V.; Rudnitskaya, Y.S.; Yakubovskaya, N.Y. Feroxyhyte, a new modification of FeOOH. Int. Geol. Rev. 1977, 19, 873-890. [CrossRef]

178. Nishida, N.; Amagasa, S.; Kobayashi, Y.; Yamada, Y. Synthesis of Cu-doped $\delta$-FeOOH nanoparticles by a wet chemical method. J. Nanopart. Res. 2018, 20, 181. [CrossRef]

179. Nishida, N.; Amagasa, S.; Ito, H.; Kobayashi, Y.; Yamada, Y. Manganese-doped feroxyhyte nano-urchins produced by chemical methods. Hyperfine Interact. 2018, 239, 33. [CrossRef]

180. Jurkin, T.; Štefanić, G.; Dražić, G.; Gotić, M. Synthesis route to $\delta$-FeOOH nanodiscs. Mater. Lett. 2016, 173, 55-59. [CrossRef]

181. Pinto, I.S.; Pacheco, P.H.; Coelho, J.V.; Lorençon, E.; Ardisson, J.D.; Fabris, J.D.; de Souza, P.P.; Krambrock, K.W.; Oliveira, L.C.; Pereira, M.C. Nanostructured $\delta$-FeOOH: An efficient Fenton-like catalyst for the oxidation of organics in water. Appl. Catal. B 2012, 119, 175-182. [CrossRef]

182. Chagas, P.; Da Silva, A.C.; Passamani, E.C.; Ardisson, J.D.; de Oliveira, L.C.A.; Fabris, J.D.; Paniago, R.M.; Monteiro, D.S.; Pereira, M.C. $\delta$-FeOOH: A superparamagnetic material for controlled heat release under AC magnetic field. J. Nanopart. Res. 2013, 15, 1544. [CrossRef]

183. Li, Y.; Fu, F.; Cai, W.; Tang, B. Synergistic effect of mesoporous feroxyhyte nanoparticles and Fe(II) on phosphate immobilization: Adsorption and chemical precipitation. Powder Technol. 2019, 345, 786-795. [CrossRef]

184. Pinakidou, F.; Katsikini, M.; Paloura, E.; Simeonidis, K.; Mitraka, E.; Mitrakas, M. Monitoring the role of Mn and $\mathrm{Fe}$ in the As-removal efficiency of tetravalent manganese feroxyhyte nanoparticles from drinking water: An X-ray absorption spectroscopy study. J. Colloid Interface Sci. 2016, 477, 148-155. [CrossRef] [PubMed]

185. Kokkinos, E.; Soukakos, K.; Kostoglou, M.; Mitrakas, M. Cadmium, mercury, and nickel adsorption by tetravalent manganese feroxyhyte: Selectivity, kinetic modeling, and thermodynamic study. Environ. Sci. Pollut. Res. 2018, 25, 12263-12273. [CrossRef] [PubMed]

186. Tresintsi, S.; Simeonidis, K.; Estradé, S.; Martinez-Boubeta, C.; Vourlias, G.; Pinakidou, F.; Katsikini, M.; Paloura, E.C.; Stavropoulos, G.; Mitrakas, M. Tetravalent manganese feroxyhyte: A novel nanoadsorbent equally selective for As(III) and As(V) removal from drinking water. Environ. Sci. Technol. 2013, 47, 9699-9705. [CrossRef]

187. Hu, J.; Lo, I.M.; Chen, G. Performance and mechanism of chromate (VI) adsorption by $\delta$-FeOOH-coated maghemite $\left(\gamma-\mathrm{Fe}_{2} \mathrm{O}_{3}\right)$ nanoparticles. Sep. Purif. Technol. 2007, 58, 76-82. [CrossRef]

188. Pereira, M.C.; Garcia, E.M.; da Silva, A.C.; Lorençon, E.; Ardisson, J.D.; Murad, E.; Fabris, J.D.; Matencio, T.; de Castro Ramalho, T.; Rocha, M.V.J. Nanostructured $\delta$-FeOOH: A novel photocatalyst for water splitting. J. Mater. Chem. 2011, 21, 10280-10282. [CrossRef]

189. da Silva Rocha, T.; Nascimento, E.S.; da Silva, A.C.; dos Santos Oliveira, H.; Garcia, E.M.; de Oliveira, L.C.A.; Monteiro, D.S.; Rodriguez, M.; Pereira, M.C. Enhanced photocatalytic hydrogen generation from water by $\mathrm{Ni}(\mathrm{OH})_{2}$ loaded on $\mathrm{Ni}$-doped $\delta$-FeOOH nanoparticles obtained by one-step synthesis. RSC Adv. 2013, 3, 20308-20314. [CrossRef]

190. Bigham, J.; Carlson, L.; Murad, E. Schwertmannite, a new iron oxyhydroxysulphate from Pyhäsalmi, Finland, and other localities. Mineral. Mag. 1994, 58, 641-648. [CrossRef]

191. Sestu, M.; Navarra, G.; Carrero, S.; Valvidares, S.M.; Aquilanti, G.; Pérez-Lopez, R.; Fernandez-Martinez, A. Whole-nanoparticle atomistic modeling of the schwertmannite structure from total scattering data. J. Appl. Crystallogr. 2017, 50, 1617-1626. [CrossRef]

192. Zhang, Z.; Bi, X.; Li, X.; Zhao, Q.; Chen, H. Schwertmannite: Occurrence, properties, synthesis and application in environmental remediation. RSC Adv. 2018, 8, 33583-33599. [CrossRef] 
193. Paikaray, S.; Schröder, C.; Peiffer, S. Schwertmannite stability in anoxic Fe(II)-rich aqueous solution. Geochim. Cosmochim. Acta 2017, 217, 292-305. [CrossRef]

194. Miyata, N.; Takahashi, A.; Fujii, T.; Hashimoto, H.; Takada, J. Biosynthesis of Schwertmannite and Goethite in a bioreactor with acidophilic Fe(II)-oxidizing betaproteobacterium strain GJ-E10. Minerals 2018, 8, 98. [CrossRef]

195. Xu, Y.; Yang, M.; Yao, T.; Xiong, H. Isolation, identification and arsenic-resistance of Acidithiobacillus ferrooxidans HX3 producing schwertmannite. J. Environ. Sci. 2014, 26, 1463-1470. [CrossRef]

196. Song, Y.; Liu, Y.; Wang, H. Comparison of the biological and chemical synthesis of schwertmannite at a consistent $\mathrm{Fe}^{2+}$ oxidation efficiency and the effect of extracellular polymeric substances of Acidithiobacillus ferrooxidans on biomineralization. Materials 2018, 11, 1739. [CrossRef]

197. Kumpulainen, S.; Räisänen, M.-L.; Von der Kammer, F.; Hofmann, T. Ageing of synthetic and natural schwertmannites at pH 2-8. Clay Miner. 2008, 43, 437-448. [CrossRef]

198. Qiao, X.; Liu, L.; Shi, J.; Zhou, L.; Guo, Y.; Ge, Y.; Fan, W.; Liu, F. Heating changes bio-schwertmannite microstructure and arsenic(III) removal efficiency. Minerals 2017, 7, 9. [CrossRef]

199. Zhang, J.; Shi, J.; Zhang, S.; Zhou, L.; Xu, J.; Ge, Y.; Fan, W.; Liu, F. Schwertmannite adherence to the reactor wall during the bio-synthesis process and deterioration of its structural characteristics and arsenic(III) removal efficiency. Minerals 2017, 7, 64. [CrossRef]

200. Birch, W.D.; Pring, A.; Reller, A.; Schmalle, H.W. Bernalite, $\mathrm{Fe}(\mathrm{OH})_{3}$, a new mineral from Broken Hill, New South Wales: Description and structure. Am. Mineral. 1993, 78, 827-834.

201. Welch, M.; Crichton, W.; Ross, N. Compression of the perovskite-related mineral bernalite $\mathrm{Fe}(\mathrm{OH})_{3}$ to $9 \mathrm{GPa}$ and a reappraisal of its structure. Mineral. Mag. 2005, 69, 309-315. [CrossRef]

202. Han, J.; Ro, H.-M. Identification of bernalite transformation and tridentate arsenate complex at nano-goethite under effects of drying, $\mathrm{pH}$ and surface loading. Sci. Rep. 2018, 8, 8369. [CrossRef]

203. Grundl, T.; Delwiche, J. Kinetics of ferric oxyhydroxide precipitation. J. Contam. Hydrol. 1993, 14, 71-87. [CrossRef]

204. Chen, Z. Synthesis of monodisperse organic-and water-soluble iron oxide nanoparticles using $\mathrm{Fe}(\mathrm{OH})_{3}$ as precursor. J. Exp. Nanosci. 2014, 9, 406-414. [CrossRef]

205. Pinto, P.S.; Lanza, G.D.; Ardisson, J.D.; Lago, R.M. Controlled dehydration of $\mathrm{Fe}(\mathrm{OH})_{3}$ to $\mathrm{Fe}_{2} \mathrm{O}_{3}$ : Developing mesopores with complexing iron species for the adsorption of $\beta$-Lactam antibiotics. J. Braz. Chem. Soc. 2019, 30, 310-317. [CrossRef]

206. Thuy, L.T.X.; Cuong, L.P.; Yabutani, T. Removal of trace metals from aqueous solution by $\mathrm{Fe}(\mathrm{OH})_{3}$ coprecipitation and flotation using poly-glutamic acid. Int. Res. J. Pure Appl. Chem. 2014, 4, 797-804. [CrossRef]

207. Arefi, M.; Saberi, D.; Karimi, M.; Heydari, A. Superparamagnetic $\mathrm{Fe}(\mathrm{OH})_{3} @ \mathrm{Fe}_{3} \mathrm{O}_{4}$ nanoparticles: An efficient and recoverable catalyst for tandem oxidative amidation of alcohols with amine hydrochloride salts. ACS Comb. Sci. 2015, 17, 341-347. [CrossRef]

208. Yan, J.; Tang, H.; Lin, Z.; Anjum, M.N.; Zhu, L. Efficient degradation of organic pollutants with ferrous hydroxide colloids as heterogeneous Fenton-like activator of hydrogen peroxide. Chemosphere 2012, 87, 111-117. [CrossRef]

(C) 2020 by the authors. Licensee MDPI, Basel, Switzerland. This article is an open access article distributed under the terms and conditions of the Creative Commons Attribution (CC BY) license (http://creativecommons.org/licenses/by/4.0/). 